\title{
Juntos en la casa común, con María, la madre de Jesús Una lectura de Hch 1,12-14 en el contexto de pandemia
}

\author{
Carolina Bacher Martinez - Fabricio Forcat - Leandro Verdini ${ }^{*}$ \\ bachermartinez@uca.edu.ar; fabricioforcat@uca.edu.ar; lav@uca.edu.ar \\ Facultad de Teología - Pontificia Universidad Católica Argentina \\ Recibido 15.08.2020/ Aprobado 25.09/2020 \\ DOI: https://doi.org/10.46553/teo.57.133.2020.p95-140
}

\section{RESUMEN}

El artículo aborda la centralidad de María en la vida cristiana a partir de la relectura de Hch 1,12-14 en el contexto del año mariano nacional 2020 marcado por la pandemia y la cuarentena. La reflexión desarrolla los fundamentos bíblicos y teológicos de la fontalidad del conocimiento amante de María, y su lugar en el afecto materno de la Iglesia, como punto de apoyo a una pastoral que prioriza la confiada piedad mariana y la presencia solícita y maternal de los cristianos en los hogares, en la sociedad y en la casa común.

Palabras clave: María; Hch 1,12-14; Conocimiento afectivo; Pastoral popular; Pandemia Together in the Common Home, with Mary, the Mother of Jesus

A Reading of Acts 1: 12-14 in the Context of a Pandemic

ABSTRACT

The article deals with the central role of Mary in Christian life from the rereading of Acts 1,12-14 in the context of the 2020 national Marian year signed by the pandemic and the quarantine. The reflection develops the biblical and theological foundations of the fontality of the loving knowledge of Mary, and its place in the maternal affection of the Church, as a point of support for a pastoral activity that prioritizes

- Los autores son profesores en la Facultad de Teología de la Pontificia Universidad Católica Argentina, en los departamentos de Pastoral, Moral y Sagrada Escritura respectivamente. 
the confident Marian piety and the caring and maternal presence of Christians at home, in society and in the common home.

Keywords: Mary; Acts 1,12-14; Affective knowledge; Popular pastoral; Pandemic

\section{Introducción}

«Sobre María recae el cuidado de que el fuego pentecostal del Espiritu Santo no se apague y de que su pascua no se enfríe... Como el pulmón en el cuerpo, así ella actúa en el interior de la Iglesia a fin de darle su aire espiritual para respirar y su fuerza, consuelo y aliento; a fin de darle alegría en medio de todas las apreturas, y nuevo impulso y entusiasmo pentecostal en medio de todos los cansancios». Card. Walter Kasper ${ }^{1}$

El año 2020 transcurrió marcado por la pandemia suscitada por el Covid-19 y expandida por toda la aldea global. En primer lugar, como reflexiona M. Navarro Puerto es difícil comparar las peculiares experiencias acontecidas en los diversos países. Sin embargo, las personas «tienen en común la experiencia de sentirse en tierra de nadie y sentir una forma de soledad difícilmente expresable». ${ }^{2}$ La vida conocida se suspendió. La medida de la cuarentena en vistas al cuidado de la salud pública marcó con el silencio el espacio público. La cercanía del otro se percibió como peligrosa y atemorizante. El miedo al contagio redujo las interacciones humanas y, en ocasiones, generó procesos de estigmatización del vecino. ${ }^{3}$ La soledad tomó protagonismo: la cuarentena profundizó dicha experiencia vital y desafío la vida cotidiana de todos, pero especialmente de los adultos mayores. El temor de los que conviven quedó plasmado en «sobresaltos vividos con la fría sensación de que de repente se nos va la vida propia o de los que amamos». ${ }^{4}$ En contraste, para algunos, la misma convi-

1 Walter Kasper, Maria, signo de esperanza (Santander: Sal Terrae, 2020), 30.

2 Mercedes Navarro Puerto, «Experiencias de la Pandemia. Evocaciones bíblicas», acceso el 10 de mayo de 2020, https://www.religiondigital.org/el_blog_de_x-_pikaza/experiencias-pandemia-evocaciones-biblicas-Mercedes

3 Cf. Rosario Purilla cm, «¿Por qué tiene miedo?», CLAR LVIII (Edición Especial 2020), 2433, 28-29.

4 Lucía Caram, «Que vuelva la alegría a nuestras calles», en: A. Spadaro et al, Covid 19, Vol. 2, M. A. Editores, 2020, 44-46, 45. 
vencia constituyó un desafío para las relaciones entre los integrantes de las familias, de las comunidades de vida consagrada, y sacerdotal. Se puede afirmar que en este marco creció progresivamente la percepción de la fragilidad propia y de la precariedad de los vínculos. ${ }^{5}$ Ha sido un tiempo en el que resurgió la pregunta por la presencia o ausencia de Dios en/tras esta pandemia. Con distintas expresiones emergieron los interrogantes: ¿Por qué Dios lo permite y calla? ¿Es un castigo? ¿Hay que pedirle a Dios milagros? ${ }^{6}$

En segundo lugar, este tiempo puso de manifiesto las injusticias sociales y agravó los dolores de muchos, ya que la pandemia no afectó a todas las personas o grupos por igual ni con la misma intensidad. Al decir de B. Sousa Santos hay muchos que están al sur de la cuarentena: los trabajadores informales, las personas sin techo, las que habitan en las villas urbanas o en los barrios populares sin acceso a servicios básicos, la gente anciana, las mujeres, las personas inmigrantes sin papeles, las comunidades indígenas, las personas discapacitadas y las que se encuentran encarceladas. ${ }^{7}$ En América Latina aún recae sobre las mujeres la triple carga horaria de trabajo doméstico y del cuidado de los demás. Las mujeres se encuentran más expuestas al virus ya que constituyen el $70 \%$ del personal de la salud. ${ }^{8}$ Pero, sobre todo, la necesaria cuarentena ha potenciado el incremento de la violencia doméstica y de los femicidios. ${ }^{9}$ Las denuncias han aumentado a nivel global. ${ }^{10}$

5 Cf. Gustavo Yáñez González, «Fragilidad y tiranía (humana) en tiempos de pandemia», en Sopa de Wuhan, Giorgio Agamben et al (APSO, 2020), 139-143, 141

$6 \mathrm{Cf}$. Víctor Codina, «¿Por qué Dios permite la pandemia y calla? ¿Es un castigo? ¿Hay que pedirle milagros? ¿Dónde está Dios?», en Covid 19, Vol. 1, V. Codina et al, (M.A. Editores, 2020), 9-12, 10-11.

7 Cf. Boaventura De Sousa Santos, La cruel pedagogía del virus (Buenos Aires: CLACSO, 2020), 45. Cf. Juan José Tamayo, «La compasión en un mundo desigual y en tiempos de pandemia», en Covid 19, Vol. 3, Pablo D'Ors, (M. A. Editores, 2020), 62-67, 66-67.

$8 \mathrm{Cf}$. António Guterres, «La pandemia expone y explota desigualdades de todo tipo, incluida la de género», acceso el 10 de mayo de 2020, https://www.un.org/es/coronavirus/articles/guterres-covid-19-expone-desigualdad-genero

$9 \mathrm{Cf}$. Sonia Montecino, «Coronavirus y $18 \mathrm{O}$ : lo que no se resuelve y queda reprimido saldrá de nuevo», en Covid 19, Víctor Codina et al, vol. 1, (M.A. Editores, 2020), 91-96, 94.

$10 \mathrm{Cf}$. Guterres, «La pandemia expone...». 
Este tiempo también ha sido, un espacio de solidaridad y creatividad. Frente a la emergencia alimentaria se ha potenciado el servicio de comedores y viandas, desde ámbitos civiles, gubernamentales y eclesiales. ${ }^{11}$ También la práctica educativa desplegó iniciativas creativas utilizando las redes sociales o espacios en medios de comunicación masivos. ${ }^{12}$ Las comunidades eclesiales han desarrollado instancias virtuales de encuentro, oración, celebración y cuidado. ${ }^{13}$ La naturaleza ha dado algunos indicios de recomposición ambiental, que rápidamente se desvanecieron al recuperarse el ritmo laboral. ${ }^{14}$

La Iglesia argentina transcurrió este tiempo de incertidumbre y dolor en el contexto del Año Mariano Nacional. Desde la reflexión teológica se abrieron algunos interrogantes: ¿Qué puede aportar la figura de María a una teología que reflexiona en contextos de incertidumbre por la pandemia? ¿Qué lugar ocupa y está llamada a ocupar la piedad mariana en las comunidades cristianas de nuestro país en un presente que se manifiesta como perturbador y amenazante de la vida? ¿Es igual en los agentes pastorales que en la piedad de los cristianos más sencillos? Estos interrogantes mantienen su actualidad en medio de cuestionamientos a las propuestas de oración en tiempos difíciles y la centralidad de María en la piedad popular.

El artículo aborda estos interrogantes desde la perspectiva bíblica, sistemática y pastoral. La reflexión es fruto del trabajo colaborativo de tres autores en diálogo. ${ }^{15}$ Para abordar la temática se propone, en la primera sección, el análisis del texto de Hch 1,12-14

11 Cf. Adle Hernández, «La cotidianiedad del barrio y las medidas ante el covid-19», Aurora No 1 (2020): 37-38, 38.

12 Cf. Diana Viñoles, «Las clases no volverán a ser lo mismo», Vida Pastoral Año LXI . $\mathrm{N}^{\text {* }}$ 386 - julio - agosto 2020, 34-36.

13 Cf. Enrique C. Bianchi, «Celebremos juntos cada uno en su casa», Vida Pastoral Año LXI - $N^{\circ} 386$ - julio - agosto (2020): 19-22.

14 Cf. Organización de las Naciones Unidas, Covid 19 en Argentina: Impacto socioeconómico y ambiental, acceso el 25 de agosto de 2020, http://www.onu.org.ar/stuff/Informe-COVID-19-Argentina.pdf, 70-72.

15 La situación de la pandemia global significó un desafío para toda la humanidad. Como grupo de investigación, también debimos establecer una forma nueva de encuentro y trabajo. Con la ayuda de las plataformas virtuales, programamos es pacios de diálogo para el intercambio y planificamos estrategias de escritura individual y corrección conjunta. Disciplinas teológicas distintas dialogaron en función de un mismo discurso. Cf. Giuseppe Ruggieri, Chiesa sinodale (Roma: Laterza, 2017), 191-206. 
y en especial el lugar central que ocupa María, la madre de Jesús, permaneciendo en oración junto a los apóstoles, las mujeres y los hermanos. Semejante retrato ha sido muchas veces meditado en la tradición teológica del cristianismo. Partiendo del análisis exegético antecedente, la segunda sección sistemática contempla y valora el lugar singularísimo de la Santísima Virgen en la fe del pueblo cristiano ofreciendo dos claves teologales: la fontalidad del conocimiento amante de María, y su lugar en el afecto materno de la Iglesia. El tercer aporte, retoma las claves antecedentes para realizar un discernimiento teológico-pastoral de la situación de pandemia y de los desafíos pastorales, ofreciendo dos propuestas para tiempos difíciles. Es un artículo a seis manos que ha brotado del fraterno sentir común de quienes han vuelto a beber en la fuente siempre abierta del corazón de María, y se sienten hijos de esa Iglesia que a dos milenios de distancia sigue naciendo del Espíritu, diversa y frágil.

\section{1. ¿Quiénes somos para que la Madre del Señor venga a visitarnos?}

"Se trata de Maria "la que escucha y recibe" la Palabra, la que "ofrece" generosamente al Padre el Hijo convertido en "varón de dolores", la que siente nacer en su corazón silencioso y pobre,

la Iglesia de la misión y la profecía». ${ }^{16}$

Cuando se presenta en el libro de los Hch a la comunidad que se prepara perseverando en la oración, para la fiesta de pentecostés, encontramos nombrada a María, con su relación de maternidad: «la madre de Jesús» $(1,14)$. Este texto de carácter eclesiológico nos permite mirarla como miembro eminente de la comunidad eclesial. Su presencia resalta en la narración y suscita en los lectores la pregunta por su reaparición.

16 Eduardo Francisco Pironio, "María y la vida contem plativa" en: De Pablo VI a Juan Pablo II (Buenos Aires: Patria Grande, 1981), 19. 
Los cuatros evangelistas mencionan a María en sus obras. Al final de la vida del Señor, solo Juan nos recuerda que se encontraba acompañando a su Hijo en su muerte. Ninguna fuente la menciona luego en los relatos de resurrección:

«La otra curiosidad es que no hay mención de ninguna aparición posresurreccional a María, la madre de Jesús. También ella es excluida de las apariciones indicadas en Hch 1,1-11. Pero tampoco hay referencia a una aparición a María en la lista (autorizada) de testigos ofrecida en 1Co 15,5-7, ni (lo que es más sorprendente) en ninguno de los evangelios; ese privilegio lo tienen en Mt 28,8-10 unas mujeres cuyos nombres no se mencionan y, en Jn 20,11-18, María Magdalena. Que de esas constataciones pueda obtenerse alguna conclusión significativa es algo que ignoro». ${ }^{17}$

Lc la señala en las vísperas de pentecostés, de un modo simple y sin desarrollos ni menciones posteriores en el libro de los Hechos. Ella había sido protagonista al comienzo de la obra lucana, en los inicios de la vida de Jesús. Luego solo fue aludida en dos oportunidades, sin casi protagonismo (cf. Lc 8,19-21; 11,27). Su reaparición en los Hch pone a los lectores ante un interrogante ¿Qué rol ocupa María en esa comunidad de discípulos? Eso nos permitirá comprender su rol hoy en las nuevas comunidades de seguidores.

Para pensar el lugar y la aparición de María en los Hch, es preciso revisar el comienzo del evangelio (cf. Lc 1-2). Allí Ella fue la primera protagonista de la historia salvífica narrada por este evangelista. Ella es presentada guardando la memoria de su Hijo.

\subsection{María en los comienzos de la obra lucana}

Ella aparece por primera vez en el evangelio de Lc en el relato de la anunciación del Ángel o de la concepción de Jesús. Es sabido que esa perícopa no solo expresa el anuncio de un nacimiento; sino también la vocación de María. ${ }^{18}$ El mensajero Gabriel saluda y convo-

17 James Dunn, Comenzando desde Jerusalén (Estella: Verbo Divino, 2012), 190.

$18 \mathrm{El}$ texto es un relato de anuncio de nacimiento (cf. Gn 16,7-14; Jc 13,1-7) que también presenta algunos rasgos típicos de la forma de relato vocacional, cf. Ignace de la Potterie, María 
ca a María con palabras que describen su identidad y a la vez forjan su destino. Se utiliza el saludo escatológico de los profetas a la Hija de Sión (cf. Sof 3,14-17; Jl 2,21-23; Za 9,9) y se utiliza un vocativo que reemplaza el nombre de la persona: «llena de gracia». ${ }^{19}$ Un saludo de semejante envergadura, genera un evidente desconcierto en el personaje (cf. Lc 1,29) que requiere la explicación pertinente de la propuesta (cf. Lc 1,30-33). La Virgen formulará entonces su desconcierto con una pregunta esencial: cómo ser madre sin conocimiento de varón (cf. Lc 1,34). El ángel le responderá asegurándole que «para Dios ningún suceso será imposible» ${ }^{20}$ (Lc 1,37). Lucas utiliza allí el vocablo $\dot{\rho} \eta \dot{\mu} \alpha$, el cual «designa más bien un acontecimiento prometido que una simple palabra». ${ }^{21}$ Son estos sucesos / acontecimientos / cosas, cargados de vida - con hechos y palabras- los que María conserva, madura e interpreta. Lo lleva a cabo desde la visita del ángel, cuando se confió totalmente a Dios y se dispuso a que la ṕn $\mu \alpha$ experimentada se haga en ella (cf. Lc 1,37-38).

La visita a su prima Isabel se enmarca a continuación de la visita que María recibió del ángel. Ella confirma su disponibilidad y servicio a la Palabra (cf. Lc 1,38), «habiéndose levantado... con prontitud $\gg^{22}$ para ir a la casa de Zacarías. Isabel proclama a los gritos (cf. Lc 1,42) que María es Bendita como su Hijo y luego la llama Bienaventurada por haber creído que las cosas o sucesos ( $\tau$ oĩs) serán llevados a su cumplimiento. María entonces proclama el Magnificat (Lc 1,46-55), un canto de alabanza puesto en sus labios para cantar

en el misterio de la alianza (Madrid: Biblioteca de Autores Cristianos, 1993), 33-38; Salvador Muñoz Iglesias, Los evangelios de la infancia, II (Madrid: BAC, 1986), 18-20.

19 Kecharitöménē puede tener un sentido físico, pero por el contexto, también tiene un evidente sentido moral. Es un participio de perfecto que designa algo que sucedió en el pasado y cuyo efecto permanece constantemente.

20 Normalmente traducimos păn rērna «todo suceso» (nosotros lo afirmamos en negativo "ningún» debido al ouk) como «nada».

21 François Bovon, El evangelio según san Lucas, I (Salamanca: Sígueme, 1995), $116 . \mathrm{El}$ sentido es el mismo que en Hch 10,37.

22 Se utiliza el verbo anistèmi (levantarse, resucitar. Cf. Mc 16,9; Lc 24,7.46). En las narraciones vocacionales se utiliza este verbo en la LXX que traduce el qûm hebreo, cf. 1 Sa 3,8; 1 Re 19,3-8; Jon 1,2-3; 3,2. Por eso, es muy coherente Lc en su utilización debido a que, «levantándose» María responde vocacionalmente a su llamado. No deja de ser significativa la utilización del verbo anístēmi como palabra double-duty, María comienza a insertarse en el proceso pascual de su Hijo. 
las maravillas de Dios y reconocer que seré considerada como una bienaventurada por todas las generaciones (cf. Lc 1,48).

Los sucesos se continuaron (cf. 1,65). Luego del alumbramiento de su hijo (cf. 2,15.17), ella se ejercita en sopesar, contemplar, reflexionar y con cuidado guardar lo esencial de todo lo vivido (cf. 2,19). A los pocos días del nacimiento, presentaron en el templo de Jerusalén al niño, allí le escuchó decir al viejo Simeón una alabanza gozosa por haber visto realizada la $\dot{\eta} \mu \alpha$ del Señor (cf. 2,29); así como también oyó la profecía que éste le aventuró. Simeón le anunció que su corazón sería atravesado por una espada. ${ }^{23}$ Este oráculo Ella lo maduró desde su obediencia a la Palabra de Dios que fue una daga que atravesó su alma durante toda su vida; puesto que los «pensamientos» intencionados de los hombres no son los de los de un discípulo. ${ }^{24} \mathrm{Su}$ obediencia a la Palabra de Dios se evidenció en su confiada esperanza en Dios. La «caída y elevación de muchos» (Lc 2,34 ) era el fruto de la acción del Dios de Israel, tal como manifiesta en su canto (comparar 2,34 con 1,52-53).

Pasados doce años del nacimiento de su Hijo, Lucas presenta un recuerdo en el que nuevamente visitan el Templo del Señor (cf. 2,$22 ; 2,41-42$ ). Por segunda vez la familia que vivía en Nazaret peregrina a la casa de Dios. La presencia del niño, que antes había sido solo percibida por dos ancianos que esperaban el consuelo de Dios (cf. 2,25.38), ahora será patente para todo el pueblo, pues lo encontrarán dialogando con los maestros de la Ley a la vista de todos (cf.

23 «Si hay que deducir el significado de 2, 35a de referencias a María en Lc-Hch, el sentido es entonces que ella, como parte de Israel, debe ser juzgada por su reacción última hacia el niño puesto para caída y alzamiento de muchos. Aunque una mujer de entre la multitud la bendiga por su relación física con Jesús, éste insistirá en que también a ella se aplica el criterio de bendición aplicado a otros: "Dichosos más bien..." $(11,27-28)$... Con la figura de una espada atravesando el alma de María, Lucas describe presumiblemente el difícil proceso por el que aprende que la obediencia a la palabra de Dios trasciende los lazos familiares. Hasta ahora ha presentado a María pasando la prueba de la obediencia $(1,38.45)$, pero ha insinuado también que el aprendizaje constituye un proceso incesante $(2,19)$, y aquí insiste en que ese proceso no es inmune a peligros y sufrimientos» Raymond Brown et al, María en el NT, $155-156$.

24 Los «pensamientos (dialogismoi) de muchos corazones» a los que se refiere Simeón, definen, por lo general, «el proceso mental de aquellos que se oponen activamente a Jesús (cf. 5,21-22; 6,8; 9,46-47; 12,17; 20,14)» Luke Timothy Johnson, The Gospel ok Luke (Collegeville, Minnesota: The Liturgical Press) 1991, 56. 
2,46-47). Los doce años representan el alcance de la mayoría legal del niño. A esa edad se debe comenzar a practicar la Ley. La entrada de Jesús en la adolescencia puso a María ante una nueva exigencia. ${ }^{25}$ Ella necesitó comprender que los designios de Dios podían acarrear un dramatismo insospechado. Cuando el niño, que había llegado con los padres (cf. 2,43) dejó de ser visto por ellos, fue hallado a los tres días en el Templo en medio de una discusión con los maestros de la Ley (cf. 2,46-47). Su crecimiento se hizo notable para todos. En el diálogo que se reproduce después del encuentro, María le reprocha el comportamiento que tanta angustia les había ocasionado a sus padres. Jesús le responde: «¿Por qué me buscaban? ¿No sabían que en los asuntos de mi Padre es necesario que esté?» $(2,49) .{ }^{26}$

En la declaración de Jesús, realizada en forma de pregunta retórica, aparece por primera vez en el evangelio el impersonal dề (es necesario). Este vocablo se utiliza para designar una necesidad absoluta, que no se puede cuestionar y de naturaleza determinística. Lucas aplica el término a la historia de salvación, como expresión de algo dispuesto por Dios y que debe realizarse, y que culminará en la muerte, la resurrección y la exaltación del Señor:

«En la obra lucana, el verbo tiene connotaciones muy peculiares. Naturalmente, no se excluye la referencia a una "necesidad" de tipo abstracto, casi óntico; pero no es eso lo principal. Lo verdaderamente lucano es el carácter histórico-salvífico del impersonal dề; el designio de salvación, la voluntad del Padre, centrada en la personalidad histórica de Jesús, "tiene que cumplirse" $^{27} .^{27}$

25 La perícopa se encuentra separada de los anteriores relatos de infancia con un sumario (LC 2,39-40) que informa del crecimiento de Jesús y finaliza con otro sumario que parece perseguir la misma finalidad (LC 2,51-52). De esta forma el texto da cuenta de un momento puntual en la vida de Jesús que expresa su desarrollo personal en todos los niveles físico, psíquico y espiritual.

26 Esos «asuntos o cosas» ( $\tau$ oĩs) habían sido mencionados por Isabel cuando pronunció a María una bienaventuranza por haber creído «las cosas anunciadas» (cf. 1,45. También cf. $24,18)$ y luego se utiliza también para expresar la admiración de María y de José ante las «cosas» dichas por Simeón (cf. 2,33. También cf. 11,45).

27 Joseph Fitzmyer, El evangelio según Lucas // (Madrid: Cristiandad, 1981), 286. Este «verbo que le gusta emplear a Lucas, significa que la relación entre el Padre y el Hijo se inscribe en la historia de la salvación. El afecto de Jesús al Padre responde al designio de Dios para con él. Esta reciprocidad se manifiesta en la economía de la salvación, que no hay que ver ni como puramente funcional, ni como abstractamente ontológica, sino como relacional, con una relación de amor y de conocimiento». François Bovon, El evangelio ... 232-233. El verbo lo encontramos 
Estas son las primeras palabras que le escuchamos decir a Jesús en el evangelio de Lucas $(2,49)$, en ellas se manifiesta su programa de vida, la necesidad de efectuar el designio de Dios y de cumplir la voluntad del Padre para realizar una historia de salvación. María deberá conectarse irrevocablemente con estos sucesos, con esta vida, porque es madre del que los realiza. Ella los guardaba en su corazón de madre y de discípula.

En dos oportunidades y con dos frases similares, el evangelista hace referencia a su actitud ante todo lo acontecido. La primera con el niño recién nacido ante el testimonio que le dieron los pastores, la segunda se refiere en el sumario que finaliza el recuerdo del crecimiento de su Hijo:

«...y María todos estos sucesos, ${ }^{28}$ sopesándolos, ${ }^{29}$ los guardaba cuidadosamente* en su corazón» (Lc 2,19).

«...Y su Madre conservaba ${ }^{* *} 30$ todos los sucesos en su corazón» (Lc 2,51b).

El corazón ocupa en el Nuevo Testamento correlación con su significado en el Antiguo Testamento:

«... el término "corazón” (kardia), en continuidad con la concepción hebrea, designa el centro de la persona en cuanto sede de los sentimientos ( $R \mathrm{~m} 9,2$; 10,1; 2Co 2,4; 6,11; Flp 1,7), de los pensamientos más recónditos ( $\mathrm{Rm} 8,27$; $1 \mathrm{Co} 4,5 ; 14,25 ; 1 \mathrm{Te} 2,4)$ y de las decisiones religiosas y morales (Mc 7,21; Rm $10,9 ; 1 \operatorname{Co} 7,37 ; 2 \operatorname{Co} 9,7) \gg .{ }^{31}$

Allí era donde ella conservaba todo, el mismo que sería traspasado por la Palabra de Dios, «es el centro de la vida, lugar donde se piensa, ama y decide. En el centro de su vida, con amor, María

con este sentido en: Lc 4,$43 ; 9,22 ; 12,12 ; 13,33 ; 17,25 ; 19,5 ; 21,9 ; 22,37 ; 24,7.44$; Hch 1,21 ; 3,$21 ; 4,12 ; 5,29 ; 9,6.16 ; 14,22 ; 16,30 ; 19,21 ; 20,35 ; 23,11 ; 25,10 ; 27,24.26$.

28 Pท́ $\mu \alpha \tau \alpha$ traducimos por sucesos, podría ser «cosas, as untos». Se corresponde con el hebreo dābār (palabra y cosa).

$29 \sum v \mu \beta \alpha \dot{\lambda} \lambda v_{\sigma} \alpha$ este participio proviene del compuesto de syn «con» y ballein «arrojar», literalmente sería que ella combinaba las cosas que había visto, oído y retenido, y así captaba el verdadero sentido.

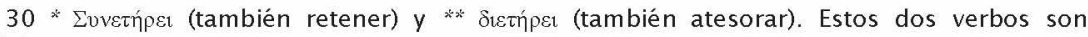
sinónimos.

31 Pontificia Comisión Bíblica, «Qué es el hombre?» Un itinerario de antropología bíblica, nº 21. 
medita». ${ }^{32}$ Medita todos estos acontecimientos, los conecta con la gracia, los transita desde la fe y los atraviesa con la Palabra de Dios.

\subsection{María en Hechos}

La Virgen es mencionada en los comienzos del libro, cuando los seguidores de Jesús se preparaban para recibir la promesa que el Señor les había hecho (cf. Hch 1,4).

«Entonces volvieron a Jerusalén desde el monte llamado de los Olivos, el cual está cerca de Jerusalén, el camino de un sábado y cuando llegaron, subieron a la habitación de arriba donde se alojaban Pedro y Juan; Santiago y Andrés; Felipe y Tomás; Bartolomé y Mateo; Santiago el de Alfeo, Simón el Zelota y Judas de Santiago. Todos ellos perseveraban unánimes en la oración con las mujeres y con María la madre de Jesús y sus hermanos» $(1,12-14)$.

En el texto se puede reconocer la forma llamada «sumario», 33 que contiene dentro, en este caso, una lista de nombres. Este tipo de descripciones genéricas se prestan para enlazar narraciones. ${ }^{34}$ Por lo general, en los Hch describen la situación de la Iglesia, como se percibe tanto desde adentro, como desde afuera. El sumario suele ser utilizado por el autor para presentar a distintos personajes y hacerlos confluir juntos, de esa manera la narrativa hace converger las distintas tramas desplegadas en cada sección, por ejemplo: Lc 8,1-3; Hch 2,42-44; 4,32-37; 5,12-16. En este caso el autor hace coincidir: a

32 Antonio Rodríguez Carmona, Evangelio según san Lucas (Madrid: BAC, 2014), 51.

33 El sumario, tal como da a entender Bultmann, es una de las formas más antiguas de la tradición que deriva incluso de tradiciones rabínicas análogas (cf. Rudolf Bultmann, Historia de la tradición sinóptica (Estella: Verbo Divino) 2000, 429). Suele funcionar como resumen en el que se ordenan de modo breve algunas actividades (cf. Mc 1,32-34; 6,53-56). «El Evangelio de Marcos proporcionó a Lucas el ejemplo más inmediato de tal empleo de resúmenes. En Hechos hay breves resúmenes, fácilmente reconocibles como construcciones redaccionales $(1,14 ; 6,7$; 9,31 -32), así como resúmenes más largos (2,42-47; 4,32-35; 5,12-16). Estos pasajes no introducen material nuevo, sino que simplemente compendian» Hans Conzelmann, Acts of the Apostles (Philadelphia: Fortress Press, 1987), xliii.

34 En el caso propio del libro de Hch, algunos tienen la característica de ser numéricos porque se proponen realzar el número de gente implicada, parecen frecuentes en toda la obra lucana: Lc 4,42-44; 8,1-4; $21,37-38$; Hch 2,41-47; 4,32-35; 5,12-16; 6,7; 9,31. 
los apóstoles, ${ }^{35}$ las mujeres, María y los hermanos. Los sumarios son así "el signo de una teología de la continuidad", ${ }^{36}$ que manifiesta en los acontecimientos contados, la vitalidad espiritual de la Iglesia.

La continuación que garantiza este sumario es un tiempo que comienza con la ascensión del Señor y finaliza con pentecostés. El acontecimiento cristológico ocurre 40 días después de su pasión (cf. Hch 1,3). ${ }^{37}$ La fiesta judía de shavu'ot, cuando Lc narra la primera manifestación del Espíritu en el libro de Hch, acontece 50 días después de pesaj. Por lo tanto, entre la ascensión del Señor y el derramamiento del Espíritu transcurre un tiempo de 9 días. Una novena dedicada a la oración y a la vida común. Un tiempo, seguramente, de diálogo, recogimiento y silencio en el que también se resolvieron cuestiones importantes. Reconstituyeron el número doce de los apóstoles, que volvía a cimentar el germen del nuevo pueblo (cf. 1,15-26). Este lapso se caracteriza por la experiencia de necesidad. Todos habían quedado mirando las alturas (cf. 1,11) cuando el cielo les arrebató a Jesús. Comenzaban un tiempo de recogimiento que los conducirá a su interioridad, a revisar en la memoria los recuerdos y en el corazón sus certezas y afectos, temores e interrogantes. Allí irrumpirá la fuerza vivificante del Espíritu.

Esta comunidad congregada «perseveraba unánime en la oración». El participio proskartepoũntes (del verbo proskarteréō «estar siempre a disposición, perseverar»), busca resaltar la continuidad de la acción. El adverbio homothymadòn «unánimes» aparece varias veces en Hch (cf. 2,46; 4,24; 5,12; 7,57; 8,6; 12,20; 15,25; 18,12; 19,29). Podemos también traducirlo por «una misma mente» o «un mismo propósito». Se utiliza para designar en los sumarios la armonía ejem-

35 Dentro de la perícopa, como se dijo, Lucas añade una lista de los nombres de los apóstoles con algunas variantes a las otras halladas, que probablemente tenga que ver con los intereses de su obra (LC 6,14-16; Mc 3,16-19; Mt 10,2-4).

36 Daniel Marguerat, "Los Hechos de los Apóstoles" en Introducción al Nuevo Testamento (Bilbao: Desclée De Brouwer) 2008, 118. Se trata de la preocupación por mostrar continuidad en la historia de la salvación.

37 «Para Lc el número 40 podría, naturalmente, estar asociado con las figuras de Moisés y Elías (Ex 34,28; Dt 8,2; 1Re 19,8)» Luke Timothy Johnson, The Acts of the Apostles (Collegeville, Minnesota: The Liturgical Press, 1992), 25. 
plar de los cristianos. Finalmente, la «oración», el término proseuje $e^{38}$ «funciona, frecuentemente, como una designación para las casas de oración judías, que eran lugares de reunión».39 En la obra lucana, es frecuente que el Espíritu se aguarde en oración Lc 3,21-22; 11,13; Hch 4,$31 ; 8,15 ; 9,11.17 ; 10,4.9 .31 .44 ; 13,2-3 .^{40}$

La comunidad estaba conformada por: los apóstoles, las mujeres, María y los hermanos. Todos ellos habían sido aludidos en los relatos de la pasión, muerte y resurrección del Señor (los apóstoles y las mujeres). ${ }^{41}$ Solo de sus hermanos no se hallan referencias explícitas en esos momentos. ${ }^{42}$ Detrás de este último grupo se oculta una de las personalidades más importantes de la era apostólica, considerado una de las «columnas de la Iglesia» (cf. Ga 1,19). Nos referimos a Santiago, el hermano del Señor (Mt 13,55; Mc 6,3). ${ }^{43}$ Representante más importante del grupo de los hermanos, obispo de la iglesia de Jerusalén. En Hch lo encontramos como el referente principal de la

38 Es un tema típico en Hch 2,$42 ; 3,1 ; 4,24 ; 6,4.6 ; 7,59-60 ; 8,15 ; 9,11.40 ; 10,2.4 .9 .30-31$; 12,$5 ; 13,3 ; 14,23 ; 16,13.25 ; 20,36 ; 22,17 ; 27,29 ; 28,8$.

39 Craig Keener, Acts. An Exegetical Commentary, Vol. I (Grand Rapids: Baker Academic, 2012), 751.

40 También se repite en el esquema: deseo del Reino y oración por su venida, junto por la plegaria por el don del Espíritu (cf. Lc 11,2.13; Hch 1,8.14).

41 Probablemente haya que buscar la identidad de este grupo de mujeres innominadas en Lc $8,2-3 ; 23,49.55 ; 24,10$. Parecerían formar parte de este todas las que «lo habían seguido desde Galilea» (Lc $23,49.55 ; 24,6$ ) y que se encontraban presentes en los eventos de su pasión y muerte, y en su resurrección. Entre ellas se encontraban: María de Magdala (Lc 8,2; 24,10a), Juana mujer de Cusa un administrador de Herodes (LC 8,3a; 24,10b), Susana (LC 8,3b), María la de Santiago (24,10c), María la de Cleofás (si la identificamos como la compañera de camino de Cleofás rumbo a Emaús en Lc 24,13; cf. Jn 19,25; Eusebio, Historia Eclesiástica 3,1 1; 3,32,6; 4,22,4) y otras más nombradas con anterioridad ( $\mathrm{Lc} 24,10 \mathrm{~d} ; 8,3 \mathrm{c}$ ). Mateo incluso cuenta, que a este grupo femenino el Resucitado les concedió el privilegio de tener la primera experiencia de su presencia (Mt 28,9-10). Juan le otorga el honor solo a María de Magdala (In 20,11-18), "de apostolorum apostola» según como es Ilamada en el nuevo prefacio confeccionado para su fiesta. Para profundizar en la identidad de estas mujeres y en la organización de las fuentes y testimonios, remitimos a: Elisa Estevez, Qué se sabe de... Las mujeres en los origenes del cristianismo, Estella, Verbo Divino, 2012, 83-90.

42 Algunos ven su mención en el grupo de los «conocidos» (gnōstoi, Lc 23,49). Aunque, probablemente, se haya utilizado ese vocablo para mencionar a otros muchos personajes que estuvieron presentes en los acontecimientos finales del Señor y las fuentes que provenían de Mc no los mencionaban, como, por ejemplo, Cleofás entre otros. La cuestión es difícil dilucidarla, si nos apoyamos en Jn 19,25 vemos que hay una referencia a la tía de Jesús: «Junto a la cruz se encontraban... la hermana de su madre, María mujer de Cleofás». Si como dijimos, en la nota anterior, asumimos que este Cleofás es el mismo que caminaba hacia Emaús, con su pareja María (Lc 24,13.18) -cuestión plausible pero imposible de probar- se trataría entonces en este caso, entre el grupo de testigos de la pascua, de la presencia de parientes de María y de Jesús.

43 Los hermanos son nombrados en el evangelio, cuando junto con la madre de Jesús, se presentaron para acercarse a Él y no podían hacerlo a causa de la multitud (cf. Mc 3,31; Lc 8, 19 21). Por el tema de su hermandad sanguínea remitimos a: John Meier, Un judío marginal, tomo I (Estella: Verbo Divino, 1998), 326-341. 
comunidad jerosolimitana (cf. 12,12.16-17). ${ }^{44}$ En definitiva, la sucinta mención de «sus hermanos» no cambia la significativa mención de la «Madre de Jesús» que reaparece en la obra lucana.

El Señor les había prometido a sus discípulos que vendría (epérjomai) sobre ellos el Espíritu Santo para que fuesen sus testigos (cf. Hch 1,8). Se indica así que el mismo Espíritu de Dios que fecundó el nacimiento del Mesías, también fecundará el nacimiento del pueblo mesiánico. Aunque sobre María ya había venido (epérjomai) el Espíritu (cf. Lc 1,35), ahora ella, la madre de Jesús acompañaba a la comunidad. Investida ya de la dýnamis de Dios (cf. Lc 1,35), participa con su oración humilde (cf. Lc 1,48), persistente (cf. Hch 1,14) y suplicante de la misma petición de la comunidad, que también será investida con la misma dýnamin espiritual (cf. Hch 1,8). Al igual que Isabel, que había sido visitada por la Madre del Señor (cf. Lc 1,43) y «fue llena del Espíritu Santo» (eplēsthē pneúmatos hagíou, Lc 1,41); en la comunidad que acompaña la Madre de Jesús (cf. Hch 1,14), «fueron llenos todos del Espíritu Santo» (eplēsthēsan pántes pneúmatos hagíou, Hch 2,4). María, por lo tanto, está ligada al derramamiento del Espíritu, y ella presencia su unción vivificadora:

«Puede (que Lc) no supiera mucho más de su ulterior vida, más ha cuidado de trazar un diseño coherente de ella desde el primer anuncio de la buena nueva hasta la víspera del advenimiento del Espíritu, que impulsaría su difusión desde Jerusalén hasta el confín de la tierra $($ Hch 1,8$)$. La primera respuesta de María a la buena nueva fue, "He aquí la esclava del Señor. Hágase en mí según tu palabra". La verdadera relevancia de Hch 1,14 está en recordar al lector que su actitud no había cambiado».45

44 Pablo lo nombra primero entre los «notables» (Gal 2,9) y lo reconoce testigo privilegiado del Resucitado (1 Co 15,7). Lucas, seguramente, supo de la jerarquización de Santiago, debido a la gracia concedida ( 1 Co 15,7); pero también es cierto, que guardó en sus escritos el mismo orden en el «que figuraba hacia el final de la serie de 1 Co $15,5-7 \ldots$ hay que notar que (como Pablo) Santiago, hermano de Jesús, no figura entre "los apóstoles"» James Dunn, Comenzando ... 190.). Las fuentes lo presentan como una gran personalidad de los orígenes (Hch 15,13-14; 21,18; Gal 1,19 Josefo, Ant, XX, 9, 1; Eusebio, Hist Ecle, II, 23). En tiempos de Hegesipo (s. II), fuente única de Eusebio para hablar de Santiago, tenía fama de santidad (cf. Eusebio, Hist. Ecle. II, 23, 4-6). Cf. Bruce Chilton and Jacob Neusner, The Brother of Jesus (London: Westminster John Knox Press) 2001, 138-159.

45 Raymond Brown y otros, María en el Nuevo Testamento (Salamanca: Sígueme,1986), 174. 
¿Para qué se hizo presente María entre ese grupo de seguidores? ¿Qué podía ofrecerle al grupo de discípulos? Ella se había convertido en testigo para los futuros mártyres (cf. Hch 1,8; Lc $24,48)$, puesto que ya había sido ungida por el santo poder de la sombra del Altísimo (cf. Lc 1,35) y había modelado su corazón de discípula a lo largo de toda su vida. Probablemente, su recuerdo de Jesús, desde el origen mismo de su concepción, así como también, las cosas ( $\tau$ oĩs) o los sucesos ( $\dot{\eta} \eta \mu \alpha)$ que vivió junto a su esposo José durante la infancia y juventud de su Hijo estaban guardadas y discernidas en su corazón materno. La Palabra de Dios ya había atravesado todo su ser transformándola en verdadera discípula (cf. Lc 11,28). Había acompañado desde lejos el ministerio público de Jesús sabiendo que Él era el Salvador, Mesías y Señor (cf. 2,11.38). En las vísperas de Pentecostés cuando la encontramos reunida junto a los apóstoles, las mujeres y familiares, todos son ya «hermanos de Jesús» y por lo tanto hijos de Ella. Esta comunidad que luego iba a experimentar muchas diferencias y discrepancias la encontramos unida con el testimonio mariano (cf. Hch 6,1; 8,1; 15,36-40; Gal 2,1-14, etc.). María era la raíz de todos ellos que le permitía a cada uno, conocer su propia vocación, la hondura propia del ser donde habitaría el Espíritu. María también les enseñaba a esperar la altura a la que Dios los llamaba, que era la plenitud para la cual su Hijo los había preparado. Su discipulado era testimonio, su maternidad era ternura.

«En medio de todos los testigos se encontraba María, con la pureza de su fe y la peculiaridad de su testimonio: sólo ella podía testimoniar lo oído, visto y meditado desde los primeros inicios (Lc 1,2). Después de la efusión del Espíritu, el seguimiento y el discipulado adquieren una nueva configuración: los seguidores y los discípulos de Jesús pasan a ser llamados "los creyentes" (Hch 2,44; 4,32). Es precisamente así, como Lc nos había presentado a María desde los inicios de su evangelio. La Madre es la primera creyente (Lc 1,45), los hijos heredamos su fe». ${ }^{46}$ 


\section{El conocimiento afectivo de María, Madre de Jesús y de la Iglesia}

«La Virgen fueen suvidaejemplo deaquel afectomaterno, conelque es necesario que estén animados todos los que cooperan a la misión apostólicadela Iglesiaparalaregeneración deloshombres». (LG65)

Suele reclamarse frecuentemente a la teología sistemática haber concentrado mucho la reflexión mariológica en los privilegios singulares de María. A partir de Lumen Gentium, se viene intentando que resplandezca más la luz de la Santísima Virgen en el misterio de la salvación, y su fuerza activa en la evangelización de la Iglesia desde sus comienzos. En América Latina, la fe del pueblo sencillo ve a la Virgen no sólo al lado de Dios sino además del lado de Dios, y no tiene reparos en contemplarla como término de la vida del hombre y centro de la vida cristiana. Inspiradas en la sección bíblica antecedente, también estas reflexiones quieren mirar a la Virgen en el centro de la escena de Hch 1,12-14. ¡Sí, en el centro! ${ }^{47}$ Buscaremos ofrecer algunas razones que ayuden a contemplar esa presencia, que la intencionalidad teológica del evangelista Lucas ha destacado al comienzo de su segunda obra. ${ }^{48}$ Tal como lo hizo en su evangelio en el nacimiento de Jesús -antes de la vida pública del mesías- en el libro de los Hechos presenta la figura materna de María en las nacientes de la Iglesia, a la espera del Espíritu Santo, antes de toda actividad evangelizadora. En ambas situaciones, en actitud de oración, María guarda en el corazón el palpitar de esa vida nueva que su animación contribuye a engendrar.

En paralelo con los dos puntos del apartado bíblico precedente centramos la mirada en la Madre de Jesús, que portadora del Espíritu desde la anunciación y concepción del Mesías, coopera ahora

47 Juan Pablo II ha titulado la II a parte de la encíclica Redemptoris Mater con el sugestivo título de La Madre de Dios en el centro de la Iglesia peregrina. Juan-Pablo-II, «Encíclica Redemptoris Mater (25 de marzo de 1987)», AAS 79 (1987) n² 5 (En adelante RMa en el cuerpo del texto).

48 Los sumarios son así "el signo de una teología de la continuidad". Cf. Supra nota 36. 
en el nuevo nacimiento que está por acontecer. ${ }^{49}$ Este paralelismo nos da la oportunidad de pensar dos claves teologales que pueden contribuir a la fecundidad de la mariología y a la valoración de su lugar singularísimo en la fe del pueblo cristiano. A partir del análisis exegético ofrecido -aunque ya dentro del género de meditación teológica-, nos detenemos en el contenido teologal del corazón de María (1); y su lugar en el corazón de la Iglesia (2). Como se verá, el primer punto quiere señalar la fuente, el segundo, motivarnos a beber constantemente de ella. Nuestro aporte hace de puente con las reflexiones pastorales del tercer apartado. De allí que centramos nuestra opción en señalar algunas dimensiones de la mariología vivida en América Latina, de las que la teología sistemática suele ayunar. ${ }^{50}$

\subsection{El corazón de María}

En paralelo con el primer punto del apartado bíblico nos detenemos en el significado teológico de ese guardar todas las cosas en el corazón que Lucas destaca de María en dos oportunidades al comienzo de su evangelio. ${ }^{51}$ Con el evangelista centramos nuestra mirada en el corazón de María ¡la llena de gracia! ${ }^{52}$ La Madre de Jesús es la única persona adulta mencionada en los evangelios de la infancia que reaparecerá en el ministerio público de Cristo, y en el nacimiento de la Iglesia, comunidad de los creyentes. Su presencia no se limita ciertamente a ser un testigo ocular o memorialista de la

49 Hch 1,12-14 en paralelo con Lc 2,19.51. Cf. Supra nota 45. También «la reflexión teológica deberá interpretar esta presencia y responder a las preguntas que se originen». James Dunn, Comenzando..., 190.

50 En orden a su recepción, seguimos algunas reflexiones del padre Rafael Tello, a quien en 2012 el Card. Bergoglio Ilamó «el teólogo de la Virgen. Un Continente tan mariano como el nuestro no podía dejar de darnos un teólogo así. Amaba profundamente a María y entendía que entre ella y nuestro pueblo pobre se fue tejiendo una singular historia de amor. Fue baqueano en seguir su huella maternal entre ellos». Jorge Bergoglio, "Prólogo," en Pobres en este mundo, ricos en la fe. La fe de los pobres de América Latina según Rafael Tello, (Buenos Aires: Ágape, 2012), 11.

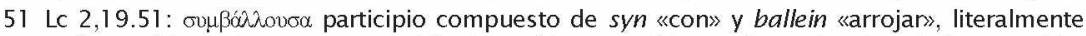
sería que ella combinaba las cosas que había visto, oído y retenido, y así captaba el verdadero sentido.

$52 \mathrm{Lc} 1,19 \mathrm{El}$ texto de la anunciación con rasgos típicos de la forma de relato vocacional, cf. nota 19. Kecharitóménē puede tener un sentido físico, pero por el contexto, también tiene un evidente sentido moral. Es un participio de perfecto que designa algo que sucedió en el pasado y cuyo efecto permanece constantemente. 
información con que los primeros cristianos componían los relatos y textos sagrados..$^{53}$ En el corazón de esta Madre vibra un tipo de conocimiento que es mucho más que información. Toda la historia de su vida, ungida por el santo poder de la sombra del Altísimo se ha convertido en fuente de una connaturalidad afectiva única en su género. La profundidad de esa fuente hunde sus raíces en el dinamismo amante del Dios Uni-trino que eternamente ha elegido a María, y en la plenitud de los tiempos ha convocado su corazón lleno de gracia:

«Había Alguien lleno de vida, de gozo, tanto, que necesitaba desbordar, tanta hermosura que para poder expresar eso creó todo lo lindo que vemos. Derramó la hermosura y la belleza y lo hizo con una mujer. Cuando Dios creó, lo hizo con una mujer. "Antes que se estableciera el firmamento yo estaba con Él y jugaba con el orbe de la tierra" (Prov. 8,30). Una niña que jugaba, un Dios que desborda de fuerza, de Vida y una niña que juega. " $Y$ mi delicia era jugar con los hijos de los hombres" (Prov. 8,31) dice la niña. Dios creó el mundo enamorado de una mujer. ¿Puede Dios enamorarse? ¿Y de una mujer? No es una figura. ¿Dios se puede enamorar de nosotros?». ${ }^{54}$

En el humilde corazón de esta hija de Sión se ha manifestado, «en cierto sentido, toda la gloria de su gracia, aquella con la que el Padre nos agració en el Amado. Llena de gracia es el nombre nuevo expresado en la vocación de María que revela la hondura y fontalidad de su corazón $\gg .{ }^{55}$ El plan divino de la salvación, revelado plenamente en Cristo, es eterno. Abarca a todos los hombres, pero

53 Cf. Raymond E Brown, María en el Nuevo Testamento: Una evaluación conjunta de estudiosos católicos y protestantes (Madrid: Sígueme, 1982), 146-151: «Lucas muestra la actitud inicial de María de guardar "estas cosas y sopesarlas en su corazón" como algo que la introducirá en la creyente comunidad post-pascual. Si esto es lo que Lc presupone en 2, 19. 51 , nos dice algo mucho más significativo (y más cristiano) sobre su idea de María, que el probar que se documenta en sus memorias»

54 Rafael Tello, «Cursillo de Chicas (26 al 29 de septiembre de 1974)», en El viejo Tello les habla a los jóvenes, ed. Rafael Tello (Buenos Aires: Agape - Fundación Saracho, 2020), 29-32, 29. El texto de reciente publicación compila charlas y homilías en ocasión de jornadas y retiros juveniles en la década del setenta. De allí la oralidad del estilo que sigue la lex orandi de las misas de la Santísima Virgen María donde se propone como primera lectura -entre otros- el texto de Prov 8,22-31. Cf. Conferencia Episcopal Argentina, Leccionario. Reformado por mandato del Concilio Vaticano II y promulgado por su santidad el Papa Pablo VI. Tomo III (Buenos Aires: CEA, 1989), 229.

55 Insiste el Papa Juan Pablo II «la llama así, como si éste fuera su verdadero nombre. No llama a su interlocutora con el nombre que le es propio en el registro civil: "Miryam" (María), sino con este nombre nuevo: "llena de gracia"». RMa 8. 
«reserva un lugar particular a la «mujer» que es la Madre de aquel, al cual el Padre ha confiado la obra de la salvación» (RMa 7). Allí, en el corazón de María, antes que en ninguna otra parte, se escriben los comienzos de los tiempos mesiánicos. El corazón que es el centro de la vida, donde se piensa, se ama y se decide. En el centro de su vida, arde el deseo amante de María. Así le formulaba estas cosas el padre Tello a las chicas y a los muchachos del movimiento juvenil evangelizador en la vigilia de Pentecostés del año 1976:

«Hubo un corazón, uno solo, muy pobre. Una niña, perdida en un pueblo pequeño, en un pueblo, también como pueblo muy pobre. Una niña muy pura, que amaba y, porque amaba, en su corazón abrazaba a todos los hombres. Una niña que vivía en el amor y en el ardor del deseo del bien de su pueblo. Esa niña, que no podía nada, se llamaba María. Y el deseo del corazón de esa niña, eso fue lo que vio Dios, lo que enamoró a Dios, y lo que lo hizo a Dios realizar la obra de la salvación de todos los hombres. Y esto no es tampoco poesía. Esa es la enseñanza formal del Magisterio de la Iglesia. Por el deseo -que es oración- de María, Dios apresura los tiempos». ${ }^{56}$

En la Iglesia naciente, María es sobre todo «feliz porque ha creído»: ha sido la primera en creer. (Cf. RMa 26). Sus vivencias y sentires guardados-meditados-sopesados ${ }^{57}$ en su corazón de mujer, se transforman así en una fuente singularísima de conocimiento afectivo del Dios cristiano. Y no se trata sólo de las glorias de María, también su dolor y su fatiga ${ }^{58}$ son fuente del sabor común que los cristianos bebemos en su corazón, incluso en las horas más amargas de nuestra vida. ${ }^{59}$ Sólo el conocimiento afectivo hace posible que sentires diversos sean capaces de aunarse en la misma tensión concomitante.

56 Rafael Tello, «Fragmentos de las reflexiones en la Vigilia de Pentecostés (6 de junio de 1976)», en Seguimos caminando: aproximación socio-histórica teológica y pastoral de la caminata juvenil a Luján, ed. Graciela Dotro, Carlos M. Galli, Marcelo Mitchel (Buenos Aires: Ágape, 2004), 81. Más datos sobre el MJE cf. Gabriel Rivero, comp, El viejo Tello y la pastoral popular (Buenos Aires: Patria Grande - Fundación Saracho, 2013).

57 Nota 51. $\sigma \cup \mu \beta a \alpha \lambda o v \sigma \alpha$ (combinaba las cosas que había visto, oído y retenido, captando su sentido).

58 Sobre la fatiga del corazón de María, cf. RMa 17; Jorge Mario Bergoglio, Reflexiones en esperanza (Buenos Aires: EUS, 1992) 158; Alexandre Awi Mello, Maria-lglesia: Madre del Pueblo Misionero. El Papa Francisco y la piedad popular mariana en el contexto teologico-pastoral latino-americano (Buenos Aires: Agape, 2019).

59 Cf. Carolina Bacher Martínez, José Carlos Caamaño, «Cultura y espiritualidad popular en la trama de la Asociación Madres del Dolor», en: Ciudad vivida. Prácticas de espiritualidad en Buenos Aires, coord. Virginia R. Azcuy (Buenos Aires: Guadalupe, 2014), 157-184. 
«El conocimiento afectivo, que termina en una experiencia, es un conocimiento cierto y directo que se realiza por "contacto" (al menos afectivo), por una cierta asimilación al objeto, por connaturalidad con lo conocido, de donde resulta que es también de algún modo sápido, sabroso, gustoso, pues el gozo es afecto de la unión de amor; sin embargo, esto hay que entenderlo bien, pues por la condición de lo amado también puede resultar arduo y doloroso, o parte sabroso y parte doloroso». ${ }^{60}$

Es la vida entera, su completa biografía envuelta en el Misterio de Dios, cargada de hechos, sentires y palabras, lo que María conserva, madura e interpreta en su corazón. Medita todos estos acontecimientos, los conecta con la gracia, los transita desde la fe y los transmite amando y viviendo. Allí, en su corazón de Madre se escribieron primordialmente esos sucesos que la Iglesia tiene por misión transmitir a todos los pueblos. La memoria afectiva de María se abre generosa a los cristianos de todos los tiempos.

«Nadie la ha podido sustituir en su camino; todos debemos aceptarla en la memoria y realidad creyente, como transmisora de la bienaventuranza de Dios sobre la tierra (cf. Lc 1,42). En ese aspecto, la fe de todos los cristianos conserva una clara dimensión mariana: como fundamento y base de nuestra comunión eclesial, tenemos que apoyarnos en el gesto de María; sólo si aceptamos como propia su palabra de fidelidad comprometida (Lc 1,38) podemos luego acompañarla en el misterio compartido de la Iglesia». ${ }^{61}$

En las vísperas de Pentecostés, cuando la encontramos reunida junto a los apóstoles, las mujeres y los parientes, todos son ya hermanos de Jesús y por lo tanto hijos de Ella. En su corazón materno se aúnan y sostienen. En torno a Ella, creyendo-esperando-amando, comprenden. ${ }^{62}$ Precisamente este conocimiento creyente de la Ma-

60 Rafael Tello, La Iglesia al servicio del pueblo (inédito, 1992) n 52. Cf. Fabricio Leonel Forcat, Ubi humilitas, ibi sapientia. El conocimiento afectivo en la vida cristiana en la Suma de Teología de Santo Tomás de Aquino (Disertación para obtener la Licenciatura en Teología, Director Lucio Gera, Buenos Aires: Facultad de Teología, Universidad Católica Argentina, 2001), 70.

61 Xabier Pikaza, «Pentecostés con los once, las mujeres, María y los hermanos de Jesús: Eclosión de vida, ocultamiento de mujeres», Religión Digital (2020), https://www. religiondigital. org/Maria-Pentecostes.html

62 Cf. Supra 106: homothymadòn «unánimes», en un «mismo sentir», en «armonía de corazón». Como se deduce del contexto nos referimos a la comprensión teologal que siempre es fruto de una connaturalidad afectiva, y no primeramente de la actividad raciocinativa. Cf. Ricardo Ferrara, «"Fidei infusio" y revelación en santo Tomás de Aquino. Summa Theologiae, I-II q. 100 , a. 4, adl m», Teología 23/24 (1974), 24-32, 29 s. 
dre de Jesús constituye un especial patrimonio de la revelación de Dios. Juan Pablo II insiste en que la fe de María " "precede" al testimonio apostólico de la Iglesia, y permanece en el corazón de la Iglesia... Todos aquellos que, a lo largo de las generaciones, aceptando el testimonio apostólico de la Iglesia participan de aquella misteriosa herencia, en cierto sentido, participan de la fe de María». (RMa 27, Subr. nuestro).

¿Cómo es que la fe de María permanece en el corazón de la Iglesia? ¿Cómo participamos en ella? La fe viva de la Virgen es una sinergia continua de conocimiento y amor. Dicho en las categorías propias del método escolástico, los primeros creyentes -incluso los apóstoles-, antes de cualquier tipo de articulación de la fides quae, hallaron en la intensidad afectiva de la fides qua de María, la res íntima que toda enunciación señala. En el corazón de la Madre de Jesús, la dimensión tendencial de toda fe -atribuida a la unción del Espíritu Santo, credere in Deum- alcanza el más alto conocimiento amoroso o apreciativo que la vida teologal ha sido capaz de gozar en la historia. ${ }^{63}$ Lo intensivo-cualitativo del conocimiento creyente de María es fuente de lo extensivo-cuantitativo que la Iglesia irá desplegando a lo largo de su historia. Volver la mirada a este conocimiento connatural de María nos conduce de lo relativo a lo absoluto; de los misterios al misterio; de las verdades a la verdad; del enunciado a la res. Los primeros discípulos y discípulas tuvieron principalmente este tipo de conocimiento por connaturalidad, raíz común y fuente viva de toda secundaria enunciación posterior. ${ }^{64}$ Ahora bien, esa vía afectiva de conocimiento -que fue un verdadero privilegio para ellos-, continúa abierta en el corazón de la Iglesia ¿cómo? También hoy este conocimiento afectivo-experimental

63 Sobre le credere in Deurn como aspecto tendencial y afectivo de la fe cf. STh. II-II q. 2 a. 2; también la argumentación que el Papa Francisco realiza respecto de la fe popular, cuando dice que "no está vacía de contenidos, sino que los descubre y expresa más por la vía simbólica que por el uso de la razón instrumental, y en el acto de fe se acentúa más el credere in Deum que el credere Deum". (EG 124).

64 La jerarquización principal y secundaria para relacionar connaturalidad y formulación en la vida teologal se funda en el tratado de la ley nueva de Santo Tomás de Aquino, STh. I-II, q. 106, a. 1. Cf. Fabricio Forcat, La vida cristiana popular. Su legítima diversidad en la perspectiva de Rafael Tello (Ágape-UCA-Fundación Saracho, 2017), 306s. 
permanece como auténtica fuente teologal de la vida cristiana. De esta jerarquización se siguen importantes consecuencias para una mariología capaz de valorar y aprender la fe encarnada y el amor filial presente en el catolicismo popular. ${ }^{65}$ El misterio de María y la fuente siempre abierta de su conocimiento afectivo abre en la revelación de Dios un anchísimo camino de entrada para la vida teologal de multitudes de hombres y mujeres sencillos. ${ }^{66}$ Por este camino no-conceptual -es decir, no raciocinante, de modo analítico y resolutivo-, se establecen los modos más eficaces para la transmisión de las verdades reveladas. ${ }^{67}$ Creemos sinceramente que sólo una teología afectiva capaz de rescatar la vía del conocimiento por connaturalidad podrá contribuir a acortar la grieta que existe entre los agentes pastorales y la vivencia religiosa de las multitudes del pueblo cristiano. ${ }^{68}$ El desafío vale tanto para la reflexión sistemática, como para la teología pastoral, la homilía y la catequesis.

«La Iglesia con su catequesis puede secundar la acción de la Virgen. Pero es necesario tener bien claro: puede secundarla, pero no reemplazarla. Si la Iglesia transmite una catequesis no afectiva, predominantemente cognoscitiva e intelectual, ella no secunda la de la Virgen y resultará estéril y no será recibida. La catequesis afectiva supone siempre el fomento cálido de alguna presencia previa o concomitante del objeto amado, es decir la Virgen» ${ }^{69}$

Todo este punto del conocimiento no-conceptual resulta de máxima importancia en la reflexión pastoral en orden a la evange-

65 Cf. Carlos María Galli, La mariología del Papa Francisco. Cristo, María, la Iglesia y los Pueblos (Buenos Aires: Agape, 2018), 20.

66 Cf. María del Pilar Silveira, «Maria en la Teologia: ¿Reflexiones elaboradas en despachos o en fronteras?», ATeo, Rio de Janeiro, v. 21, n. 57, p. 495-516, set./dez.2017, 506; Leandro Chitarroni, El modelo pedagógico de Nuestra Señora de Guadalupe en el Nican Mopohua (Córdoba: Talleres Gráficos Masters, 2003); Diego Irarrazaval, Maria en los pueblos latinoamericanos (2008 a 2016), inédito.

67 Cf. Rafael Tello, La nueva evangelización. Escritos teológicos pastorales (Buenos Aires: Ágape, 2008), 31: «La comunicación con la Madre -y aún la comunicación con otros respecto a la Madre- no puede humanamente quedar encerrada en los límites racionales, esto es contra la naturaleza y realidad de una relación vital, existencial, estructurante de la personalidad».

68 El calificativo "afectivo" - llamado así porque en él juega un papel determinante el amor, la voluntad o afecto- es usado por Santo Tomás. Cf. STh. I q. 64, a. I; II-II q. 97, a. 2, ad2m; q. 162 , a. $3,1 \mathrm{~m}$. En el marco acotado de este artículo hemos centrado la atención en el conocimiento afectivo más que en la teología afectiva.

69 Cf. Rafael Tello, La Virgen de Luján es formadora del pueblo de la nación argentina (Inédito, 1997). Subrayado nuestro. 
lización. El influjo de la ilustración sobre muchas expresiones de la doctrina católica moderna no ha sido suficientemente de-construido. ${ }^{70}$ Contrariamente a como se repite en ambientes más ilustrados "que no se puede amar lo que no se conoce", en la perspectiva de Santo Tomás de Aquino, puede amarse con mucha intensidad realidades muy imperfectamente conocidas, ya que el conocimiento no es la causa sino la raíz del amor. Es función del conocimiento señalar su objeto al afecto, y cuando éste está muy intensificado, tiñe, modifica y acrecienta el conocimiento, le da un tono que lo hace como nuevo y distinto, promueve una nueva y más cercana consideración de lo amado. Allí se gesta un nuevo conocimiento, una mayor comprensión de la res amada, ya que es propio del amor producir una mutua inhesión: el amado en el amante, y el amante en el amado. El conocimiento afectivo mira algo que la persona tiene por el amor, de modo que ella misma tiende a ser, estar o vivir en la cosa amada.

En el conocimiento y experiencia afectivo de realidades más nobles que el sujeto -como son Dios y la Virgen- el que conoce se asimila a la realidad conocida, se mira en relación a ella. Por esta vía de connaturalidad afectiva, la Virgen es percibida como término de la vida cristiana. «Es como flor respecto a Dios, es el sitio, lugar, -"huerto ameno" - en el cual se lo halla a Dios; la que prefiere Dios, donde hallándose el cristiano lo halla a Dios». ${ }^{71}$ Ello no resulta ajeno al conocimiento amante de Nuestra Señora que sigue viviendo, y no solamente en Dios -jen Asunción celeste!-, sino también en la memoria y la vida teologal de los fieles que participan de su mismo Espíritu mientras peregrinan a su encuentro. ${ }^{72}$

«En nuestro pueblo sencillo se conoce y siente a la Virgen como Madre y como unida y poderosa ante Dios (y en esto, por su carácter de humana, de mujer y de santa, la siente más próxima a sí y a su vida); y éste es un conocimiento esencial y predominantemente afectivo, que informa, tiñe,

$70 \mathrm{Cf}$. Rafael Tello, El cristianismo popular. Ubicación histórica y hecho inicial en América (Bs. As.: Saracho - Agape, 2016), $31 \mathrm{~s}$.

71 Cf. Rafael Tello, La "Marca" de la Cofradia, inédito, 1993. Subrayado nuestro.

72 Cf. Pikaza, "Pentecostés con los once, las mujeres, María y los hermanos de Jesús: Eclosión de vida, ocultamiento de mujeres," 
deja marcada toda la vida de la gente sencilla del pueblo. Este conocimiento afectivo es fomentado por la acción de la Virgen, que se renueva y aumenta con la continua renovación y aumento del pueblo». ${ }^{73}$

En América Latina, Dios manifiestamente congrega a nuestros pueblos mostrando su amor misericordioso y el cariño maternal de la Virgen. La fe nos conduce a «mirar y ser mirado, tocar y ser tocado, abrazar y ser abrazado por el Señor y por la Virgen. En su condescendencia, manifestada en la Encarnación, Dios quiere que experimentemos su amor y le amemos de modo connatural con nuestra humanidad». ${ }^{74}$ Aunque profundizar en ello rebalsa en mucho el objetivo de este artículo, el aunarse de nuestros pueblos en torno a una Imagen de María obedece a motivos históricos que no se pueden considerar ajenos a la Providencia divina, y que han arraigado fuertemente en la configuración mariana del catolicismo popular.

¡Cuánta mordiente histórica podría alcanzar la teología -tanto en su dimensión sistemática como pastoral- considerando verdaderamente un lugar teológico a la mariología vivida! Porque la transmisión de vida es un asunto de vida. Nada más natural, nada menos sofisticado para la persona viva de la Santísima Virgen que seguir comunicando su conocimiento-amante en la historia de la Iglesia y de los pueblos cristianos. «La Virgen Madre está constantemente presente en este camino de fe del Pueblo de Dios hacia la luz». (RMa 35). El cántico del Magníficat, expresión de la fe profunda de María no deja de vibrar en el corazón de la Iglesia, ni deja de hacerse carne en el corazón de los humildes a través de los siglos. Su amor ya eternizado permanece en el corazón de los cristianos como prenda de bienaventuranza y «brilla en nuestro camino como signo de consuelo y de firme esperanza». ${ }^{75}$

$73 \mathrm{Cf}$. Tello, La Virgen de Luján es formadora del pueblo de la nación argentina, $\mathrm{n}^{\circ} 11$. (Texto entregado por el padre Tello con fecha 4/12/97). Subrayado nuestro.

74 Carlos María Galli, «Fe y Teología: riesgo y humildad Meditar desde el corazón de María», Teología 57, n. 132 (2020), https://doi.org/https://doi.org/1 0.46553/teo.57.132.2020, https://erevistas.uca.edu.ar/index.php/TEO/article/view/3126, 34.

$75 \mathrm{Cf}$. Conferencia Episcopal Argentina, Misal Romano. $3^{a}$ Edición típica para Argentina, (Buenos Aires: $\mathrm{CEA}^{2}$ ), 475 (Prefacio IV de la BVM, María signo de consuelo y de esperanza). 


\subsection{En el corazón de la Iglesia}

El tiempo mesiánico del evangelio y el tiempo escatológico del Espíritu son inaugurados en la obra lucana resaltando el conocimiento-amante de María. Centrando su presencia «en estos dos momentos de su esquema pneumatológico, Lucas ha mostrado que existe una marcada semejanza estructural entre el origen de Jesús y el nacimiento de la Iglesia». ${ }^{76}$ La que guardaba todas las cosas en su corazón es presentada por Hch 1,14 en las nacientes de la Iglesia, participando a los diversos grupos de discípulos un sentir común en la expectativa del Espíritu.

Contemplar esta escena a la luz de la tradición de la Iglesia y en el horizonte de la historia de la salvación, destaca el lugar que ocupa María, "la hija de Sion" en el conjunto del camino del pueblo de Dios. ${ }^{77}$ En tanto Madre de Jesús, y ligada al derramamiento del Espíritu, María ocupa un lugar de privilegio, tanto en la génesis de la Iglesia como en la comunión que constituye su misma esencia. En la fecundidad de María, virgen y madre, se abriga también la frágil y diversa comunidad de los creyentes. ${ }^{78}$ Bajo su amparo se afianza la unión de los corazones de los discípulos, las mujeres, y los hermanos-parientes de Jesús en la expectativa del Espíritu Santo. Como antaño la de Cristo en Nazaret, ahora en el Cenáculo, en el ocultamiento del corazón de María, se gesta la vida pública de los cristianos.

Lo que aquí nos interesa de modo especial rescatar es precisamente esa comunión de corazones que María coopera fontalmente a

76 Xavier Pikaza, "Pentecostés con los once, las mujeres, María y los hermanos de Jesús": Lc $1,26 \mathrm{~s}$; Hch 1,14s; 2,1s

77 Cf. Ignacio de la Potterie, «María en el nuevo Testamento», en Nuevo Diccionario de Teología Bíblica, (Madrid: Ediciones Paulinas, 1990) 1136-1149, 1137.

78 Cf. Ibíd: «En medio, entre las mujeres y los hermanos de Jesús, está su madre, a la que se llama con su nombre, María. Literariamente (si el kai, es decir " $y$ " que le une a las mujeres) se podría suponer que ella está integrada en el grupo de mujeres. Habría, según esto, tres grandes componentes de la Iglesia: apóstoles, mujeres y parientes. Sin embargo, es mucho más probable que ese kaì $(y)$ que le vincula a mujeres-parientes sea disyuntivo, de modo que ella forme grupo aparte. María tiene su propia personalidad, aporta una experiencia irrepetible y diferente en el conjunto de la Iglesia». Se mantienen las dos dimensiones: por una parte, María es parte del grupo de mujeres y parientes y, por la otra, ocupa un lugar singularísimo en el plan de salvación, que la distingue sin separarla de dichos grupos. 
realizar. A esa comunidad naciente de apóstoles, mujeres y parientes, que luego el mismo libro de los Hechos nos mostrará viviendo diferencias y discrepancias, la encontramos aunada en el afecto materno de María:

«Allí en medio de ellos está María, y María que conserva todas las cosas en su corazón. María que en su corazón comprende el plan de Dios, el designio de Dios, lo que hoy llamaríamos el Plan de Salvación de Dios. María que conoce el misterio de Dios, ese designio de Dios y que lo lleva en su corazón, eleva el corazón por el amor (el Corazón Inmaculado, el Corazón Purísimo de María), eleva el corazón por el amor hacia Dios y en ese levantar el corazón a Dios reúne y arrastra tras de sí el corazón de los apóstoles».79

Su sentir es modelo y fuente de la koinonía naciente. Lo que realiza Pentecostés es una extensión de lo que ya María vive y testimonia acerca de Jesús. La vida nueva debe llevar esta marca comunional que el corazón lleno de gracia de la Virgen contribuye a realizar. ${ }^{80}$ También este privilegio singular que ese grupo diverso de primeros creyentes tuvieron aunándose en el corazón de María, continúa abierto para la acción evangelizadora de la Iglesia. Así los invitaba Rafael Tello a los jóvenes en los años setenta a ser consumados en la unidad por el corazón de María:

«La tradición, muy antigua tradición, muestra el amor de los apóstoles por la Virgen y la unión de la Iglesia cabeza. La unión de la Iglesia en los apóstoles, no es solamente la unión de hombres que tienen que resolver en común (cosas que tienen que hacer). Es mucho más que eso. Es la unión de unos corazones que son arrastrados, movidos y centrados por el corazón de María, en Dios mismo. María es centro de unidad en la Iglesia por el amor con que ama a Dios y eleva su corazón a Dios, y en Dios hace encontrar los corazones de los apóstoles. Y allí, de ese centro de unidad, es de donde surge luego una acción concertada, de conjunto, como solidaria y de todos.

Tal vez eso también tengan que comprender ustedes y pedir al corazón de María que les enseñe como puede haber una comunión, una comunidad que surja de unos mismos intereses, de una misma vida, de unas mismas cosas que hay que afrontar y que hay que resolver; pero como mucho más allá de esa comunidad, que es una solidaridad en el pensamiento, en la de-

79 Rafael Tello, Maria y la Iglesia (inédito, 1976).

80 Cf. Mercedes Navarro Puerto, "María," en El Dios Cristiano, (Salamanca: Secretariado Trinitario, 1992), 861 . 
cisión y en la acción, mucho más allá de eso, en el fondo, como raíz, como principio de eso, hay otra unidad que es la unión de los corazones en Dios». ${ }^{81}$

Un detalle no menor que Lucas nos ofrece en Hch 1,13 es que todo sucede en la casa, lugar de la koinonía y fuente de la evangelización que los primeros cristianos llevaban adelante..$^{82}$ En este tiempo nuestro, marcado también por el suspenso de la pandemia, con gran parte de la humanidad permaneciendo en la casa, este segundo punto sistemático concluye con una breve consideración sobre la Madre de Jesús como fuente del amor de los cristianos. Volvamos a contemplar esta escena, con ese tiempo que parece suspendido, con poco o nada que hacer más que esperar y confiar. Retornemos también nosotros a la raíz comunional de toda obra, centrándonos en María, la Madre de Jesús:

«la raíz de la acción salvadora, la sustancia de donde brota la esencia misma del poder salvador en la Iglesia, es el amor. De modo que en la medida en que se ama se coopera con este Dios real, que todo su ser es amar a los hombres. El amor de Dios o el amor explícito de los hombres por Dios: eso es lo que constituye como la mayor fuerza salvadora en la Iglesia a través de la historia $>{ }^{83}$

Ya de ese modo, como lugar de comunión, la casa se convierte en verdadero sacramental de la ciudad futura que esperamos, donde el afecto materno de María será pleno y definitivo. Donde la diversidad en amor consumada será transformada en sinfónica armonía trinitaria. Aunque todavía no, en el ya sí del conocimiento amante de

81 Tello, Maria y la Iglesia Con la misma radicalidad teologal expresaba esta misma sustancia evangélica a los sacerdotes que animaban la pastoral juvenil: «Nosotros lo sabemos, pero como no es perceptible nos desconcierta mucho. La fuerza salvadora más profunda que pueden tener los hombres en la Iglesia es una cosa puramente espiritual, interna, que es el amor. La fuerza salvadora más profunda que obra en la Iglesia no es la misión apostólica, no es Pablo que va recorriendo las naciones por todo el mundo grecorromano y difundiendo la Palabra de Dios. No son las obras que va haciendo la Iglesia primitiva, no. La fuerza salvadora más profunda es el amor que está en el corazón de los cristianos» Tello, «Charlas a sacerdotes del movimiento juvenil evangelizador en Tapalqué», En El viejo Tello les habla a los jóvenes, edited by Rivero Gabriel (comp). Bs. As: Agape - Fundación Saracho, 2020, 203-288, 209.

82 Por ejemplo, en Hch 12,$12 ; 18,24 ; 20,8-11$; 28,30-31; Hch 9,17; 16,34.40; 18,7-8. Cf. Rafael Aguirre, «La casa como estructura base del cristianismo primitivo: las iglesias domésticas», en Del movimiento de Jesús a la Iglesia cristiana (Estella: Verbo Divino, 2009), 83-114.

83 Tello, «Charlas a sacerdotes del movimiento juvenil evangelizador en Tapalqué». 210. 
María y en el amor de los cristianos participamos de la comunión de los santos. «Todos somos de algún modo uno. La vida de uno se hace también vida de los demás. La Virgen María es una, pero todos vamos a participar de su modo de vivir». ${ }^{84}$

\section{Balance sección sistemática}

El pequeño pasaje bíblico que contemplamos vuelve a poner a la Madre de Jesús en la trama relacional de la historia de la Salvación. La persona viva de la Santísima Virgen permanece en el centro de la escena. En comunión con Cristo y el Espíritu de pentecostés aparece para siempre como la primera cristiana de la historia. Su animación maternal continúa activa en la santificación teologal de los hermanos y hermanas de su Hijo. María no es recuerdo del pasado, ni tampoco puede ser tratada en la evangelización como un instrumento pastoral en manos de la institución eclesial. En tanto lugar de encuentro, María es huerto ameno en el cual hallándose el cristiano lo halla a Dios.

El misterio de María, y la fuente siempre abierta de su conocimiento afectivo, convocan a nuestra teología a reconocer en la revelación de Dios este anchísimo camino de auténtica vida teologal, y a descubrir con espíritu de fe la senda que transitan multitudes de hombres y mujeres sencillos. Como en aquella comunión naciente de apóstoles, mujeres y parientes, también hoy la acción y la pasión de la Iglesia se nutre de la fuente llena de gracia del corazón de María. De ese manantial de conocimiento y amor brotan continuamente en nosotros la fe inconmovible, la esperanza confiada, y el amor cariñoso a la Madre de Jesús.

84 Tello, «Cursillo de chicas (8 al 11 de mayo de 1975)». En El viejo Tello les habla a los jóvenes, comp. Gabriel Rivero. Buenos Aires: Agape - Fundación Saracho, 2020. 33-42, 42. 


\section{Secundar la actual presencia maternal de María en las diversas casas}

«Son tiempos de amar sin ver.... El cristiano no precisa ver para amar. Pero precisa amar para ver. Quien ama de verdad saborea algo de eternidad en el tiempo: el amor de Dios, a quien no se ve», ${ }^{85}$

El punto de partida de este estudio lo constituyó el interrogante sobre el lugar vital y central que ocupa María y que está llamada a ocupar la piedad mariana en el Pueblo de Dios en tiempos de incertidumbre global. La reflexión de Hch 1,12-14 ofreció elementos desde la teología lucana para profundizar en la presencia de María en la comunidad, y en su ser Madre de Jesús y de la Iglesia. Dicho resumen se ubica en un tiempo suspendido entre la Ascensión y Pentecostés que quedó configurado por la ausencia de la percepción de la presencia de Dios, de búsquedas interiores y de necesidad de horizontes. Un tiempo que convocó a la fe, a la esperanza y al amor compartido. En dicho marco, Lucas ubica la respuesta de fe de María de permanecer en la oración expectante en la compañía de las mujeres, los parientes y los apóstoles; ofreciendo, de esta manera, su mismo corazón amado y amante a través del cual conoce a Dios íntima y singularmente, y lo da a conocer de manera maternal a sus hijas e hijos. Así como se hizo presente en la hora del nacimiento de la Iglesia en América Latina, también hoy sigue convocando a cada cristiano y a cada comunidad a encontrase en la oración con ella y, adentrándose en su corazón, dejarse conducir a un conocimiento afectivo de Dios como raíz de la experiencia cristiana.

María se hace presente convocando a sus hijos a una oración compartida expectante del kairós. Este tiempo de pandemia y cuarentena, muchas veces percibido como de ausencia de la manifestación de Dios, puede comprenderse como un misterio más que como un enigma. Un misterio de fe como oportunidad de renovar la con- 
fianza en Dios presente en/tras la aparente ausencia. Una fe que no es una conquista personal, sino un don del Espíritu, alimentado a través de la meditación de la palabra en la comunidad eclesial, ${ }^{86}$ y que encuentra en María una síntesis vital paradigmática. En este tiempo de silencio forzado, se aprende la paciencia. ${ }^{87}$ También hoy María se halla presente en el Pueblo de Dios y como llena de gracia, se acerca a sus hijos dispersos y los convoca a renovar la expectativa del consuelo de Dios, compartiendo lo que ella guarda en su corazón. El pueblo fiel responde a su presencia con gestos y palabras que expresan su confianza en ella. De María la comunidad orante aprende a discernir el paso del Señor por la trama histórica en contextos de pandemia y cuarentena y a percibir la fuerza del Espíritu que la impulsa a ponerse del lado de Dios, saliendo de sí para anunciarlo con actitud y gesto maternal. Hoy el kerigma está llamado a confesarse subrayando algunas notas:

\footnotetext{
«creer y confiar en un Dios Padre-Madre creador, que no castiga, que es bueno y misericordioso, que está siempre con nosotros, es el Emanuel; creemos y confiamos en Jesús de Nazaret que viene a darnos vida en abundancia y se compadece de los que sufren; creemos y confiamos en un Espíritu vivificante, Señor y dador de vida». ${ }^{88}$
}

En Hch 1,12-14 María es la madre de Jesús que se hace presente y cuya maternidad aúna a los hijos. Ella había sido proclamada bendita entre las mujeres por Isabel (cf. Lc 1,42b), indicando con dicha expresión no sólo el haber sido elegida por Dios para formar parte de singular manera en el plan de salvación sino también su inscripción en la tradición de mujeres del Antiguo Testamento que ante algún peligro han colaborado para liberar al pueblo. ${ }^{89} \mathrm{La}$ línea de continuidad teológica en Lucas también se expresa en el eje transversal de un Dios que defiende a los pobres y a los humildes. ${ }^{90}$

86 Cf. Víctor Codina, «¿Por qué Dios permite la pandemia y calla?», 10-11.

87 Cf. Jürgen Moltmann, «Esperanza en tiempos de la pandemia del Corona», en Covid 19 , Vol. 4, Papa Francisco et al, (Santiago de Chile: M. A. Editores, 2020), 20-21, 21.

88 Codina, «¿Por qué Dios permite la pandemia y calla?», 10-11.

89 Cf. Brown et al, María en el Nuevo Testamento, 136.

90 Cf. Ibid., 143. 
Cuando la Iglesia acude al corazón de María y a la profundidad de su fe expresada en el Magníficat «renueva cada vez mejor en sí la conciencia de que no se puede separar la verdad sobre Dios que salva... de la manifestación de su amor preferencial por los pobres y humildes» (Rmi 37c). Hoy las incertidumbres y los padecimientos han resonado con fuerza y se han poblado de nombres, historias, dolores, y situaciones concretas que llegan hasta los diversos espacios cotidianos y lo transforman todo en un lugar desde el cual vivir y pensar la fe. ${ }^{91}$ Este tiempo de pandemia y cuarentena desafía la experiencia de hermandad y convoca a compartir y compartirse. Así como Lucas ubica a María al comienzo del evangelio como Madre de Jesús y al comienzo de Hechos como Madre de la Iglesia naciente, también la muestra saliendo de si y poniéndose al servicio de los próximos: en el evangelio visitando a su prima Isabel con un embarazo avanzado y en Hechos junto a las mujeres, los parientes y los apóstoles en ese tiempo caracterizado por la experiencia de necesidad, de revisión, de oración y meditación entre certezas y temores.

Hoy, ¿cómo puede la pastoral secundar esta presencia de María en el pueblo creyente? Y, ¿cómo pueden los cristianos y las comunidades hacer carne la presencia maternal de María ante los nuevos rostros sufrientes?

\subsection{Priorizar la dimensión mariana en las propuestas de oración y celebración en tiempos difíciles}

Con motivo de la situación de pandemia y cuarentena se suspendieron muchas prácticas pastorales ordinarias, entre ellas, la asistencia física de los fieles a las misas, quienes han sido exceptuados del precepto dominical. En contrapartida se amplió la difusión de las celebraciones eucarísticas a través de diversas redes, en algunos casos, propiciando la participación on-line de los bautizados. Según la observación de varios sacerdotes se constató una mayor 
presencia en estos espacios virtuales que en las celebraciones presenciales. La Comisión Litúrgica de la Conferencia Episcopal Argentina animó a las familias a realizar celebraciones de la palabra en las casas y ofreció subsidios con guiones preparados para tal fin. El Congreso Mariano Nacional «María, Madre del Pueblo, esperanza nuestra», cuyo lema fue: «Con María, servidores de la esperanza», organizado por la diócesis de Catamarca para celebrar los cuatrocientos años del hallazgo de la Virgen del Valle en los valles catamarqueños tuvo que ser postergado y luego realizarse de manera virtual. A partir de la reflexión realizada en la sección bíblica y sistemática de este trabajo interesa traer a la reflexión dos propuestas que animaron durante este incierto tiempo procesos pastorales en las casas centrados en la figura de María ya presente en gran parte del cristianismo vivido en Argentina. Uno de ellos corresponde a una práctica en la diócesis de Catamarca y otro a la propuesta del Papa Francisco para el mes de mayo.

Por una parte, la Comisión de Pastoral de la Niñez en la diócesis de Catamarca, invitó a que se prepararan mantitos de la Virgen del Valle en familia para ser colocados en las puertas de entrada de sus casas como signo de protección. La propuesta implicaba utilizar los elementos que se tuviera en el hogar. Durante el IV domingo de cuaresma, el sacerdote encargado de la comisión bendijo durante la misa transmitida por Facebook dichos mantos. ${ }^{92}$

Por otra parte, el 25 de abril del 2020 el Papa Francisco convocó a todos los fieles a rezar, de manera personal o familiar, el rosario en las casas durante el mes de mayo «en el que el pueblo de Dios manifiesta con particular intensidad su amor y devoción a la Virgen María». ${ }^{93}$ Consideró que las restricciones de la pandemia en cierta medida habían obligado a la Iglesia a valorizar esta dimensión espi-

$92 \mathrm{Cf}$. «Invitan a confeccionar mantitos de la Virgen pidiendo su protección», 28 de marzo 2020, acceso el 17 de julio 2020, https://datamarca.com/invitan-a-confeccionar-mantitos-de-la-virgen-pidiendo-su-proteccion/

93 Francisco, Carta del Santo Padre Francisco a todos los fieles para el mes de mayo 2020 , Roma, 25 de abril de 2020, acceso el 6 de julio 2020, http://www.vatican.va/content/francesco/ es/letters/2020/documents/papa-francesco_20200425_lettera mesedimaggio.pdf 
ritual doméstica. En la carta a todos los fieles, Francisco prometía su oración por todos los cristianos, especialmente por aquellos que sufrían, y animaba a rezar también por él.

Con su carta Francisco adjuntó dos oraciones a María para rezar al finalizar el rosario. Sin ánimo exhaustivo indico algunas expresiones que ayudan a comprender el lugar que se le reconoce a María en el contexto de pandemia en dichos textos. En la primera de ellas, se hace referencia a María como signo de salvación y de esperanza, y se expresa la seguridad de que María concederá lo que conoce que la humanidad necesita. En la segunda de las oraciones propuestas, se le pide a María, Madre de Dios y Madre nuestra que vuelva sus ojos misericordiosos a nosotros en esta pandemia del coronavirus. Se describen diversos sujetos afectados por la situación: se le pide que consuele y sea el sostén para aquellas personas confundidas por la enfermedad o muerte de sus seres queridos, o que están angustiadas ante el futuro incierto por la falta de trabajo; que proteja al personal de la salud; que se haga presente con los que asisten a los enfermos y con los sacerdotes; que ilumine a los hombres y mujeres de la ciencia; que asista a los líderes de las naciones para que encuentren alternativas solidarias; que mueva las conciencias para que las inversiones destinadas a las armas se transformen en inversiones sanitarias; por último, se le pide:

«Madre amantísima, acrecienta en el mundo el sentido de pertenencia a una única y gran familia, tomando conciencia del vínculo que nos une a todos, para que, con un espíritu fraterno y solidario, salgamos en ayuda de las numerosas formas de pobreza y situaciones de miseria. Anima la firmeza en la fe, la perseverancia en el servicio y la constancia en la oración». ${ }^{94}$

Se puede constatar que ambas propuestas: a) reconocen que muchos creyentes experimentan y valoran la presencia de María en sus vidas; b) fueron prácticas viables de realizar en las casas en tanto ámbitos de fe y oración doméstica; c) y priorizaron la experiencia comunitaria de oración, sin desestimar su dimensión personal. 
En el primer caso, se propuso un gesto con fuerte raigambre en la tradición cultural de la provincia y con resonancias bíblicas referidas a la celebración pascual, tiempo litúrgico en el que se inscribió la práctica. ¿Qué sentido tiene animar a los fieles a pedirle a la Virgen María que los proteja? En Catamarca, el mantito es signo de una presencia: «a todos "nos cubre el manto de la Virgen"».95 Este núcleo vital se puso en diálogo con la celebración eucarística cuando en ella se bendijo a los mantitos. La virtualidad articuló dos gestos de oración presenciales, uno litúrgico y otro popular, reconciliando dos instancias que nacieron juntas, pero crecieron separadas. ${ }^{96}$ El reconocimiento de la actual presencia de María en las casas se expresó con el signo del manto en la puerta y, como en Hch 1,14, actualizó la memoria del Hijo que permanecía oculto y del Espíritu de vida plena que se espera; siendo, al mismo tiempo, signo de la comunidad expectante reunida en torno a ella. El gesto invitó a las familias a sumergirse en la historia de ese paso misterioso de Dios entre los claroscuros cotidianos: entre temores y dolores, y entre esperanzas y compromisos. De esta manera, se ofreció un testimonio de la fe a las nuevas generaciones que los invitó a resignificarlo en la actual situación de pandemia.

En el segundo caso, el rezo del Rosario animó a entrar en el corazón discipular y maternal de María y junto a ella meditar la situación de pandemia, especialmente a través del rezo de los misterios dolorosos. Los misterios dolorosos fueron incluidos en el Rosario en el siglo XIV cuando se padecía la peste negra que eliminó gran parte de la población de Europa. De esta manera el camino de la cruz de Jesús iluminaba la cruz cotidiana. ${ }^{97}$ Francisco animó a confiar en que María sabe lo que la humanidad necesita, y a imitar la misericordia de su corazón maternal con aquellos que estaban

95 José Demetrio Jiménez, «La piedad popular: una aproximación desde el noroeste argentino», en Una historia de amor y de fidelidad. 400 años de Nuestra Señora de la Pura y Limpia Concepción, coord. Oscar Tapia, (Buenos Aires, Guadalupe: 2019), 17-76, 61-62.

96 Cf. Bernardo Olivera, Espiritualidad y mistica popular, (Buenos Aires;Talitakum Ediciones, 2015), 123.

97 Cf. Pedro Suarez, «El Rosario o «Corona de Rosas» ofrecidas a María», Anatéllei Año VII $n^{\circ} 13$ (2005): $41-47,47$. 
padeciendo la enfermedad y la pobreza. Todos los que se unieron al rezo de la segunda oración pidieron que María se hiciera presente: sosteniendo, consolando, animando al compromiso, moviendo las conciencias, y generando un proceso hacia la unidad, no sólo entre los cristianos, sino con toda la humanidad. A través del rezo del Rosario los cristianos una vez más pudieron sumergirse en la historia de salvación con sus dolores y con sus alegrías inscriptas en el horizonte de la resurrección.

En ambos casos las oraciones propuestas son de petición. Estas son formas naturales de vivir una relación de confianza en Dios ante las situaciones de peligro y angustia:

«La oración de petición no es una oración interesada, que espera ser escuchada, sino la palabra del hombre radicalmente necesitado ante la realidad de la presencia de donde viene todo don, ya que lo que ese hombre necesita ante todo es a su Dios. La decepción por la falta de escucha queda reservada a los tiempos ilustrados, que entendían la oración de petición con mentalidad utilitarista" ${ }^{98}$

María, las mujeres, los parientes y los apóstoles permanecieron unidos en oración en ese tiempo suspendido entre la Ascensión del Señor y Pentecostés. Como dan testimonio las Escrituras, no siempre se eliminan las causas de los padecimientos y de la angustia, pero la comunidad se abre a la experiencia de que Dios es el Dios con nosotros, el Espíritu vivificador de Pentecostés:

«La oración transforma el horizonte de esta situación de necesidad en un horizonte nuevo, aunque la necesidad misma se mantenga. Se trata de una situación nueva de esperanza, de consuelo, de confianza y de alegría que cambia por completo, aunque se mantenga la situación que la causó. No hay ninguna oración que no sea escuchada. Este es el sentido que suele atribuirse a la expresión "pedir con $\mathrm{fe}$ " $\gg .{ }^{99}$

98 Juan Martín Velasco, «Modesta apología de la oración de petición», Selecciones de Teología 202 (2012): 103-111, 109.

99 Velasco, «Modesta apología de la oración de petición», 111. 


\subsection{Animar la comunión en las diversas casas}

La escena que Lucas propone en Hch 1,1-14 transcurre en una casa como espacio de reunión y oración. En la visita a Isabel, María se traslada de su casa a la de su prima embarazada. En ambos espacios María desde su profunda unidad con Dios coopera a la unidad interior entre los presentes, saliendo al encuentro de los que están con necesidad. Su fe y su esperanza se configuran como amor servicial. Como en el Magnificat su bienaventuranza está unida al gozo de los pobres y sufrientes: «María aparece, así, como oyente y servidora de la Palabra, del acontecer de la Palabra de Dios. Su corazón es el centro de todo este proceso de escucha y actuación de la Palabra. Es el centro de las decisiones de María, de su libertad, de su donación personal». ${ }^{100}$

La pandemia y la cuarentena reconfiguraron la vida de gran parte de la humanidad situándola en la casa. Para algunos esto implicó una experiencia de soledad no buscada que posibilitó tanto la creatividad como la convivencia con un silencio de muerte. Para otros la vida comunitaria, ya sea familiar o consagrada, ofreció espacios de encuentro y de apoyo mutuo en la enfermedad, al mismo tiempo que también fue ámbito de fuertes tensiones en la convivencia cotidiana. Emergió con gravedad inusitada la violencia ejercida hacia algunas mujeres que, mientras buscaban protegerse del virus, en ocasiones encontraron la muerte a manos de sus vínculos cercanos. Mientras que para algunos la casa era sinónimo de seguridad, para muchas familias su residencia no ofrecía las mínimas condiciones para protegerse del virus debido a la ausencia de agua potable para la higiene. Además, la cuarentena deshabilitó el trabajo informal e independiente de muchas familias y ya no pudieron acceder al sustento necesario, teniendo que recurrir a la asistencia del Estado y de la iglesia. El sufrimiento de muchos por la enfermedad o muerte de familiares y amigos a la distancia también se hizo pre- 
sente. De esta manera la casa se configuró históricamente como un espacio ambivalente y su ponderación requiere un discernimiento a la luz de los vínculos nuevos que Jesús anunció e inauguró y que María conservó, meditó en su corazón maternal y favoreció con su amorosa presencia. ${ }^{101}$

No es posible separar a María de su condición femenina. Ella es bendita entre las mujeres. Dios quiere revelarnos algo a través de ella, que también quedó expresado en las palabras y gestos de Jesús hacia las mujeres: «la práctica del Señor introduce un germen transformador que no siempre ha sido reconocido y valorado por sus seguidores». ${ }^{102}$ De esta manera, la valoración de María como madre de Jesús reafirma también la dignidad de la mujer concreta de cada época. Para todos los discípulos esto implica un llamado a colaborar en la transformación de las condiciones sociales y culturales que posibilitan las situaciones de violencia hacia las mujeres que llegan, en no pocas ocasiones, al femicidio. Como afirma Clara Temporelli "el proceso maternal que también incluye el Magníficat nos lleva a resistir los poderes dominantes desde la creatividad que nace del amor". ${ }^{103}$

En el contexto del Nuevo Testamento la casa no solo alude a la trama familiar sino también a la red de vínculos de producción en torno a ella, de tal manera que todos aquellos que producían bienes o que dependían de estos para su subsistencia quedan referidos a la casa. Así la casa también pone en el horizonte los vínculos socioeconómicos. ${ }^{104}$ María al proclamar el Magníficat asume esta dimensión desde una maternidad profética que anuncia un Reino que es buena noticia para todos los humillados, los hambrientos y los pobres. ${ }^{105}$

101 Cf. Organización de las Naciones Unidas, Covid 19 en Argentina: Impacto socioeconómico y ambiental, 16 de junio de 2020, acceso el 25 de agosto de 2020, http://www.onu.org.ar/ stuff/Informe-COVID-19-Argentina.pdf.

102 Gustavo Gutiérrez, El Dios de la Vida (Lima: Instituto Bartolomé de las Casas/Centro de Estudios y Publicaciones, 1989), 311.

103 Clara Temporelli, María, mujer de Dios y de los pobres. Relectura de los dogmas marianos (Buenos Aires: San Pablo, 2008), 59.

104 Cf. Rafael Aguirre (ed.), Asi empezó el cristianismo (Verbo Divino: Navarra, 2010), 171.

105 Cf. García Paredes, Mariología, 99. 
La intimidad con Dios no la hizo una persona desligada de las cosas de la vida y del pueblo, sino que hizo de ella una persona muy atenta a los problemas de los otros. María así es modelo de maternidad social para todos los cristianos que están llamados denunciar las injusticias e inequidades, a experimentar y convocar a la unidad de los corazones, al cuidado de los más débiles, a compartir los bienes, y a desplegar una transformación que vuelva a situar tanto a la vivienda como al trabajo digno en la agenda pública. ${ }^{106}$

Por último, la humanidad vive como una única familia y en la biodiversidad con las demás criaturas en una casa común. ${ }^{107}$ Hoy más que nunca los cristianos están llamados a adentrarse en esta casa y a permanecer unidos entre todos los que la habitan. En la tradición mestiza del noroeste argentino, el manto de la Virgen del Valle está vinculado con la tierra que sostiene y con la vida que se ofrece. Una perspectiva que es fruto tanto de la integración en la identidad aborigen de la propuesta evangélica como del enriquecimiento de la experiencia de la fe cristiana con las tradiciones de los pueblos. ${ }^{108}$ Así la presencia de María en la casa se reconfigura como presencia en la casa común que aúna a todos los discípulos, a todos los seres humanos y también a la tierra, como hermanos. Como se hizo presente en la Iglesia naciente, María ahora cuida con afecto y dolor materno este mundo herido (cf. LS 241). Su presencia vuelve a convocar a una unidad renovada con la madre y hermana tierra.

\section{Balance sección pastoral}

La oración de petición confiada constituye la mediación adecuada para que los fieles se sumerjan en el corazón de María y renueven la esperanza para transitar los tiempos inciertos, uniéndose de esta manera a los discípulos de todas las épocas. La pastoral se

106 Cf. Francisco, La vida después de la pandernia (Vaticano: Librería Editrice Vaticana, 2020), 14. Edición en PDF.

$107 \mathrm{Cf}$. Francisco, La vida después de la pandemia, 61.

108 Cf. Jiménez, «La piedad popular», 61-62. 
pone al servicio de este encuentro animando a él y proponiendo la confianza en dicha presencia en clave responsable, esto es, invitando a expresarla y a meditar estas cosas de manera comunitaria a la luz de Cristo, muerto y resucitado, y de su Espíritu dador de vida plena.

En el encuentro, María inspira a trasladarse a la casa común y a subir a ella. Ahí los cristianos no sólo permanecen unidos, sino que aprenden a ser también presencias maternales para los demás, de tal manera que las soledades hallen compañía; los enfermos, cuidado; los hambrientos, alimento; las mujeres violentadas, alternativas; los desocupados, trabajo digno; el ambiente, la conversión ecológica. También se animan a tomar la palabra y a denunciar cuando en el hogar, en la economía y en la casa común prevalece el caos, y a anunciar las experiencias que dejan entrever el kairós: «Donde había temor, ese viento impulsa el coraje, donde había llanto y luto bloqueando la palabra, el Espíritu (ruah, pneûma) empuja el anuncio de la buena noticia, y donde había inmovilismo este mismo Espíritu anima el movimiento dinámico, la acción libre y creativa». ${ }^{109}$

\section{Conclusión general}

Las épocas de incertidumbre son tiempos donde el misterio de la vida se experimenta con intensidad y en las que el don de la fe compartida sostiene la esperanza acerca de lo que no se percibe con claridad. ¡Quién sino María nos puede enseñar a meditar estos sucesos para descubrir lo que es necesario! Desde su corazón maternal ella supo discernir y amar como una verdadera discípula y proclamar la obra de Dios para los humildes. En la casa, junto a los apóstoles, las mujeres y los parientes de Jesús perseveraron en la oración expectantes del Espíritu. Su presencia habitada por el Dios Trino los aunaba y los sostenía. Es el mismo conocimiento afectivo de María que hizo posible que sentires diversos sean capaces de aunarse en el amor. 
Ayer, hoy y siempre, la persona viva de la Santísima Virgen permanece humildemente en el centro de la escena. En comunión con Cristo y el Espíritu de pentecostés su animación maternal continúa activa en la santificación teologal de los hermanos y hermanas de su Hijo, aunándolos en la casa común e invitándolos a comprometerse con los demás. La fontalidad del conocimiento amante de María, y su lugar en el afecto materno de la Iglesia han resultado dos claves luminosas para transitar el suspenso y la fragilidad del tiempo de la pandemia, con los ojos puestos en Aquella que brilla en nuestro camino como signo de consuelo y de firme esperanza. La experiencia de nuestro pueblo latinoamericano confirma -desde hace mucho tiempo- aquella certeza vislumbrada por nuestros obispos en Puebla:

«María, Madre, despierta el corazón filial que duerme en cada hombre. En esta forma nos lleva a desarrollar la vida del bautismo por el cual fuimos hechos hijos. Simultáneamente, ese carisma maternal hace crecer en nosotros la fraternidad. Así María hace que la Iglesia se sienta familia» (DP 295).

La Iglesia se descubre llamada a reconocer y acompañar la actual presencia de María en la vida del Pueblo de Dios, invitándolo a expresar la confianza en su protección y a meditar en el misterio de la vida y de la muerte a la luz de su Hijo, muerto y resucitado. Como María, cada cristiano puede ser presencia maternal para todos los que están padeciendo en estos tiempos difíciles, promoviendo que cada casa sea un espacio de cuidado, que la economía esté al servicio del desarrollo integral, y que la tierra sea experimentada como casa común. Las familias de Dios que forman su Pueblo sostuvieron en la pandemia su fe enamorada poniendo a María en medio de sus hogares y así, al igual que aquel grupo que se constituiría Iglesia en Pentecostés, empujaron en el tiempo de cuarentena o enfermedad la esperanza común, anticipando el Reino de Dios que viene y crece en medio de la historia.

Tres enfoques confluyeron en este escrito común para discernir este tiempo difícil y la presencia amante de María en él. ¡Quién sino Ella pudo ser la fuente de unidad de la reflexión! Así como ayer subieron a la casa los discípulos -apóstoles, mujeres y parientes- los 
tres autores nos unimos en torno a María para meditar estos sucesos y discernir juntos cómo proclamar en este tiempo la Buena Noticia de Su presencia. Los puntos de vista propios de cada disciplina, al cotejarse y compartirse, se enriquecieron de otras perspectivas, y permitieron ampliar los ángulos de la visión y matizar la parcialidad de la hermenéutica disciplinar.

\section{Bibliografía}

Aguirre, Rafael, Así empezó el cristianismo. Navarra: Verbo Divino, 2010.

Awi Mello, Alexandre, Maria-Iglesia: Madre del Pueblo Misionero. El Papa Francisco y la piedad popular mariana en el contexto teologico-pastoral latino-americano. Buenos Aires: Agape, 2019.

Bacher Martínez, Carolina, y José Carlos Caamaño. «Cultura y espiritualidad popular en la trama de la Asociación Madres del Dolor». En Ciudad vivida. Prácticas de espiritualidad en Buenos Aires, cood. Virginia R. Azcuy. Buenos Aires: Guadalupe, 2014, 157-184.

Bergoglio, Jorge Mario. Reflexiones en esperanza. Buenos Aires: EUS,1992.

—, Prólogo a Pobres en este mundo, ricos en la fe. La fe de los pobres de América Latina según Rafael Tello, editado por Enrique C. Bianchi. Buenos Aires: Ágape, 2012, 11-13

Bianchi, Enrique C., "Celebremos juntos cada uno en su casa», Vida Pastoral 386 (2020):19-22.

Bovon, François, El evangelio según san Lucas, vol. I. Salamanca: Sígueme, 1995.

Brown, Raymond E., María en el Nuevo Testamento: Una evaluación conjunta de estudiosos católicos y protestantes. Salamanca: Sígueme, 1982.

Brown, Raymond, Karl P. Donfried, Joseph A. Fitzmyer, John Reumann. María en el Nuevo Testamento. Salamanca: Sígueme, 1986.

Bultmann, Rudolf, Historia de la tradición sinóptica. Estella: Verbo Divino, 2000. 
Caram, Lucía. «Que vuelva la alegría a nuestras calles». En Covid 19, vol. 2, ed. Antonio Spadaro et al. Santiago de Chile: M. A. Editores, 2020, 44-46.

Chilton, Bruce y Jacob Neusner. The Brother of Jesus. London: Westminster John Knox Press, 2001.

Chitarroni, Leandro. El modelo pedagógico de Nuestra Señora de Guadalupe en el Nican Mopohua. Córdoba: Talleres Gráficos Masters, 2003.

Codina, Víctor. «¿Por qué Dios permite la pandemia y calla? ¿Es un castigo? ¿Hay que pedirle milagros? ¿Dónde está Dios?». En Covid 19, vol. 2, ed. Antonio Spadaro et al. Santiago de Chile: M. A. Editores, 2020, 9-12.

Conferencia Episcopal Argentina, Leccionario. Reformado por mandato del Concilio Vaticano II y promulgado por su santidad el Papa Pablo VI. Tomo III. Buenos Aires: CEA, 1989

- Misal Romano. $3^{\text {a }}$ Edición típica para Argentina. Buenos Aires: $\mathrm{CEA}^{2}$.

Conferencia Epiccopal Latinoamericana y del Caribe, Documento de Puebla, 1979.

Conzelmann, Hans. Acts of the Apostles. Philadelphia: Fortress Press, 1987.

de la Potterie, Ignacio. María en el misterio de la alianza. Madrid: BAC, 1993.

De Sousa Santos, Boaventura, La cruel pedagogía del virus, Buenos Aires: CLACSO, 2020. Edición en PDF.

Dotro, Graciela, Carlos Galli, Marcelo Mitchell. Seguimos caminando: aproximación socio-histórica teológica y pastoral de la caminata juvenil a Luján. Buenos Aires: Ágape, 2004.

Dunn, James, Comenzando desde Jerusalén, vol. I. Estella: Verbo Divino, 2012.

Estevez, Elisa, Qué se sabe de... las mujeres en los orígenes del cristianismo. Estella: Verbo Divino, 2012.

Ferrara, Ricardo. «"Fidei infusio" y revelación en santo Tomás de Aquino. Summa Theologiae, I-II q100, a4, ad1m», Teología 23/24 (1974): 24-32.

Fitzmyer, Joseph, El evangelio según Lucas II. Madrid: Cristiandad, 1981. 
Forcat, Fabricio Leonel. Ubi humilitas, ibi sapientia. El conocimiento afectivo en la vida cristiana en la Suma de Teología de Santo Tomás de Aquino. Disertación para obtener la Licenciatura en Teología, Director Lucio Gera, Buenos Aires: Facultad de Teología, Universidad Católica Argentina, 2001. [en línea] <http:/ / bit.ly/2uQJR5W> [consulta: 19/I/2020].

— La vida cristiana popular. Su legítima diversidad en la perspectiva de Rafael Tello. Buenos Aires: Ágape-UCA-Fundación Saracho, 2017.

Francisco, Exhortación apostólica Evangelii gaudium (24 noviembre 2013), 220: AAS 105 (2013).

—, Carta encíclca Laudato si' (24 mayo 2015), 237: AAS 107 (2015)

- Carta del Santo Padre Francisco a todos los fieles para el mes de mayo 2020, Roma, 25 de abril de 2020, acceso el 16 de julio de 2020, http://www.vatican.va/content/francesco/es/letters $/ 2020$

—, La vida después de la pandemia. Vaticano: Librería Editrice Vaticana, 2020. Edición en PDF.

Franco Echeverri, Gloria L, «Editorial», CLAR 58 (2020): 4-7.

Galli, Carlos María «Fe y Teología: riesgo y humildad Meditar desde el corazón de María» Teología 57, no 132 (2020): 9-40, https:/ / doi.org/https://doi.org/10.46553/teo.57.132.2020. https:// erevistas.uca.edu.ar/index.php/TEO/article/view/3126.

—, La mariología del Papa Francisco. Cristo, María, la Iglesia y los Pueblos. Buenos Aires: Agape, 2018.

García Paredes, José, Mariología. Madrid: BAC, 1995.

Gasda, Élio. «Sin amor nada somos», Aurora 1 (2020): 9-10.

Guterres, António, «La pandemia expone y explota desigualdades de todo tipo, incluida la de género», acceso el 10 de mayor 2020, https://www.un.org/es/coronavirus/articles/guterres-covid-19-expone-desigualdad-genero

Gutiérrez, Gustavo, El Dios de la Vida. Lima: Instituto Bartolomé de las Casas/Centro de Estudios y Publicaciones, 1989.

Hernández, Adle. «La cotidianidad del barrio y las medidas ante el covid-19», Aurora No 1 (2020): 37-38.

«Invitan a confeccionar mantitos de la Virgen pidiendo su protección», Data Marca, 28 de marzo de 2020, acceso el 17 de julio de 
2020, https:/ / datamarca.com/invitan-a-confeccionar-mantitos-de-la-virgen-pidiendo-su-proteccion/

Jiménez, José Demetrio, «La piedad popular: una aproximación desde el noroeste argentino», en: Oscar Tapia (coord.), Una historia de amor y de fidelidad. 400 años de Nuestra Señora de la Pura y Limpia Concepción. Buenos Aires: Guadalupe, 2019, 17-76.

Johnson, Luke Timothy, The Acts of the Apostles. Collegeville-Minnesota: The Liturgical Press, 1992.

- The Gospel of Luke. Collegeville-Minnesota: The Liturgical Press, 1991.

Juan-Pablo-II, «Encíclica Redemptoris Mater (25 de marzo de 1987)» AAS 79 (1987): 361-433.

—, «Ecíclica Redemptoris missio (7 diciembre 1990)» AAS 83 (1991), 249-340.

Kasper, Walter, María, signo de esperanza. Santander: Sal Terrae, 2020.

Keener, Craig, Acts. An Exegetical Commentary, vol. I. Grand Rapids: Baker Academic, 2012.

Marguerat, Daniel, «Los Hechos de los Apóstoles». En Introducción al Nuevo Testamento. Bilbao: Desclée De Brouwer, 2008.

Meier, John, Un judio marginal, vol. I. Estella: Verbo Divino, 1998.

Moltmann, Jürgen, «Esperanza en tiempos de la pandemia del Corona». En Covid 19, vol. 4, Papa Francisco et al. Santiago de Chile: M. A. Editores: 2020, 20-21.

Montecino, Sonia, «Coronavirus y 18 O: lo que no se resuelve y queda reprimido saldrá de nuevo». En Covid 19, Vol. 1V, Codina et al. Santiago de Chile. M.A. Editores: 2020, 91-96.

Muñoz Iglesias, Salvador, Los evangelios de la infancia, vol. II. Madrid: BAC, 1986.

Navarro Puerto, Mercedes, «María». En El Dios Cristiano, ed. Xabier Pikaza, Nereo Silanes. Salamanca: Secretariado Trinitario, $1992,853-863$

«Experiencias de la Pandemia. Evocaciones bíblicas». En Religión Digital, acceso el 10 de mayo de 2020, https:// www.religiondigital.org/el_blog_de_x-_pikaza/experiencias-pandemia 
Olivera, Bernardo, Espiritualidad y mística popular. Buenos Aires: Talitakum Ediciones, 2015.

—, Siguiendo a Jesús en María. Buenos Aires: Soledad Mariana, 1997.

Organización de las Naciones Unidas, Covid 19 en Argentina: Impacto socioeconómico y ambiental, 16 de junio de 2020, acceso el 25/08/20 en: http://www.onu.org.ar/stuff/Informe-COVID-19-Argentina.pdf

Pikaza, Xabier. "Pentecostés con los once, las mujeres, María y los hermanos de Jesús: Eclosión de vida, ocultamiento de mujeres." Religión Digital (2020), https://www.religiondigital. org/Maria-Pentecostes

Pironio, Eduardo Francisco, «María y la vida contemplativa». En De Pablo VI a Juan Pablo II. Buenos Aires: Patria Grande,1981. 19-22.

Pontificia Comisión Bíblica, "¿Qué es el hombre?" Un itinerario de antropología bíblica», 2020.

Potterie, Ignacio de la. «María en el nuevo Testamento». En Nuevo Diccionario de Teología Bíblica, ed. Gianfranco Ravasi Pietro Rossano y Antonio Girlanda. Madrid: Ediciones Paulinas, 1990.

Purilla, Rosario, «¿Por qué tiene miedo?», CLAR 58 (2020): 24-33.

Rivero, Gabriel, comp. El viejo Tello y la pastoral popular. Buenos Aires: Patria Grande - Fundación Saracho, 2013.

Rodríguez Carmona, Antonio, Evangelio según san Lucas. Madrid: BAC, 2014.

Ruggieri, Giuseppe, Chiesa sinodale. Roma: Laterza, 2017.

Silveira, María del Pilar. «Maria en la Teologia: ¿Reflexiones elaboradas en despachos o en fronteras?», ATeo, Rio de Janeiro, v. 21, n. 57, (set./ dez. 2017): 495-516.

Suarez, Pedro, «E1 Rosario o «Corona de Rosas» ofrecidas a María», Anatéllei Año VII n ${ }^{\circ} 13$ (2005): 41-47.

Tamayo, Juan J, «La compasión en un mundo desigual y en tiempos de pandemia». En Covid 19, vol. 3, ed. Pablo D'Ors et al. Santiago de Chile: M. A. Editores, 2020, 62-67.

Tello, Rafael. «Charlas a sacerdotes del movimiento juvenil evangelizador en Tapalqué». En El viejo Tello les habla a los jóvenes, edited by Rivero Gabriel (comp). Buenos Aires: Agape - Fundación Saracho, 2020. 
- - «Cursillo de chicas (8 al 11 de mayo de 1975)». En El viejo Tello les habla a los jóvenes, comp. Gabriel Rivero. Buenos Aires: Agape - Fundación Saracho, 2020.

—, «Cursillo de Chicas (26 al 29 de septiembre de 1974)». En El viejo Tello les habla a los jóvenes, comp. Gabriel Rivero. Buenos Aires: Agape - Fundación Saracho, 2020.

—, El cristianismo popular. Ubicación histórica y hecho inicial en América. Bs. As: Saracho-Agape, 2016.

—, La Iglesia al servicio del pueblo. Inédito, 1992.

—, La nueva evangelización. Escritos teológicos pastorales. Buenos Aires: Ágape, 2008.

—_ La Virgen de Luján es formadora del pueblo de la nación argentina. Inédito, 1997.

—, María y la Iglesia. Inédito, 1976.

—, La "Marca" de la Cofradía. Inédito, 1993.

Temporelli, Clara, María, mujer de Dios y de los pobres. Relectura de los dogmas marianos. Buenos Aires: San Pablo, 2008.

Velasco, Juan M, «Modesta apología de la oración de petición», Selecciones de Teología 202 (2012): 103-111.

Viñoles, Diana, «Las clases no volverán a ser lo mismo», Vida Pastoral 386 (2020): 34-36.

Yáñez González, Gustavo, «Fragilidad y tiranía (humana) en tiempos de pandemia». En Sopa de Wuhan, Giorgio Agamben et al. APSO. 2020: 139-143. 